\title{
Evaluation of Eye and Respiratory Symptoms among Employees at an Indoor Waterpark Resort
}

Sophia Chiu, MD, MPH Nancy Burton, PhD, MPH, MS, CIH Kevin H. Dunn, ScD, CIH

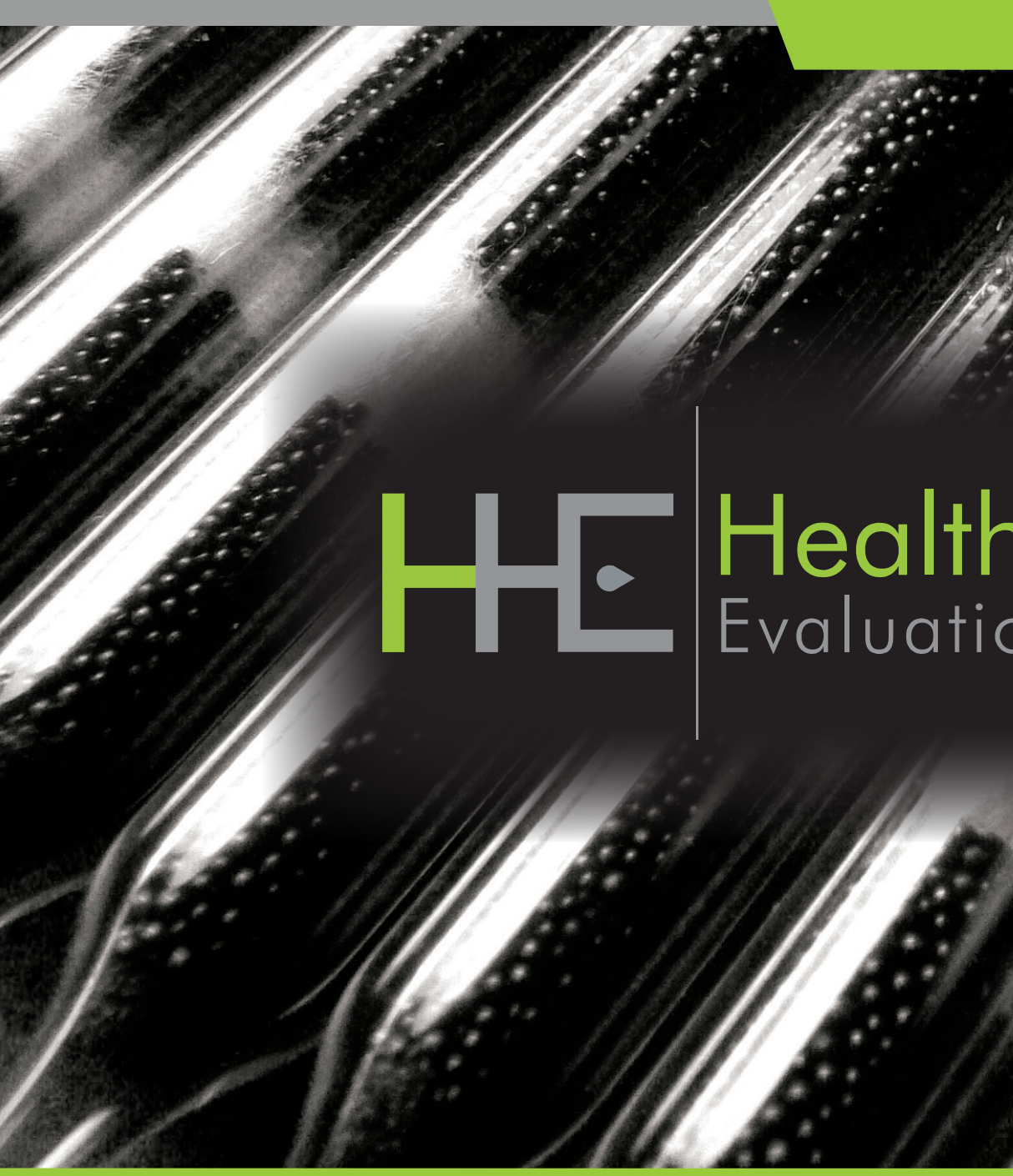

HHE Report No. 2015-0148-3272

February 2017

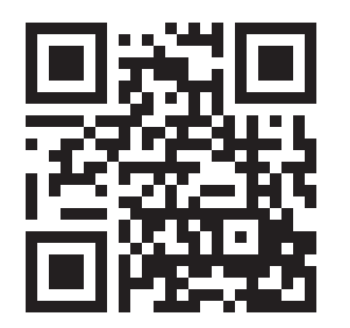

U.S. Department of Health and Human Services Centers for Disease Control and Prevention

National Institute for Occupational Safety and Health

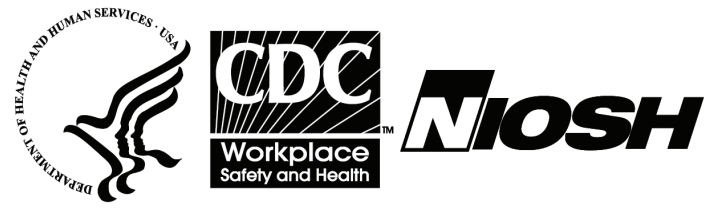




\section{Contents}

Highlights.

Abbreviations ...................................... iii

Introduction ................................... 1

Background............................................. 1

Methods .......................................... 5

Results ........................................... 8

Discussion ............................................... 17

Conclusions......................................... 21

Recommendations........................... 21

Appendix A ..................................... 24

Appendix B....................................... 31

References.......................................... 36

Acknowledgements.......................... 43

The employer is required to post a copy of this report for 30 days at or near the workplace(s) of affected employees. The employer must take steps to ensure that the posted report is not altered, defaced, or covered by other material.

The cover photo is a close-up image of sorbent tubes, which are used by the HHE Program to measure airborne exposures. This photo is an artistic representation that may not be related to this Health Hazard Evaluation. Photo by NIOSH. 


\section{Highlights of this Evaluation}

The Health Hazard Evaluation Program received a request from a local health department to evaluate symptoms and exposures to chlorine and disinfection byproducts among employees at an indoor waterpark resort. Local health department officials became concerned about eye and nose irritation, difficulty breathing, cough, and vomiting among employees when they investigated complaints from waterpark resort patrons. We visited the waterpark resort in August 2015 and January 2016.

\section{What We Did}

- We surveyed employees about their work and health.

- We tested the air for chlorine, chloroform, and endotoxin.

- We tested the water for chlorine, mycobacteria, and Legionella.

- We evaluated the ventilation systems of the waterpark.

- We measured air temperature and relative humidity in the air in the waterpark, hotel arcade, and hotel gift shop.

\section{What We Found}

- Work-related eye and respiratory symptoms were about 5 times more common among employees who worked in the waterpark than other parts of the resort. These symptoms were consistent with exposure to chemicals formed when chlorine used to disinfect pool water reacts with materials from swimmers' bodies. The chemicals that result from this reaction are known as disinfection byproducts.

We surveyed employees of an indoor waterpark resort about work-related symptoms. We evaluated the ventilation systems and indoor quality, and measured contaminants in the air. We measured low levels of airborne chlorine, chloroform, and endotoxin. The waterpark ventilation systems were not wellmaintained and several fans were not operating, which likely explains why employees in the waterpark area had more symptoms than employees in other areas.

- The waterpark's ventilation systems were not working as designed. Several ventilation fans were not working.

- Levels of endotoxins, chlorine, and chloroform in the air were low.

- Water chlorine levels were at or above the waterpark's internal guidelines.

- Waterpark air temperatures were lower and relative humidity levels were higher than the guidelines recommended.

- Respirators used by waterpark maintenance employees were not properly maintained or stored. Employees did not remember being trained on how to use them.

- Supervisors did not have employees' emergency contact information readily available. 


\section{What the Employer Can Do}

- Change the ventilation systems to ensure enough air movement, and proper dilution and removal of air contaminants.

- Train waterpark employees (including maintenance staff) on the chemical and biological hazards in the waterpark. The primary focus should start with hazards related to chlorine.

- Encourage employees to report work-related upper respiratory symptoms or other health problems. These problems can be early indications that the ventilation systems are not functioning properly.

- Ensure that respirators are properly maintained and stored, and that employees are trained on how to use them.

- Ensure that supervisors have emergency contact information for all employees readily available.

\section{What Employees Can Do}

- Report work-related health concerns to your supervisor. Upper respiratory symptoms may be a sign that the ventilation systems are not functioning properly.

- Seek medical care from your healthcare provider if you have symptoms to determine if they are related to exposures at work. If so, proper accommodations or improvements to your work environment can be made. 


\section{Abbreviations}

${ }^{\circ} \mathrm{F}$

ACGIH ${ }^{\circledR}$

ANSI

$\mathrm{CDC}$

cfm

CFR

CI

EU

HRU

HVAC

ND

$\mathrm{NIOSH}$

OEL

OSHA

PEL

ppm

PR

REL

$\mathrm{RH}$

STEL

TLV®

TWA

VFD

WEEL ${ }^{\mathrm{TM}}$

WHO
Degrees Fahrenheit

American Conference of Governmental Industrial Hygienists

American National Standards Institute

Centers for Disease Control and Prevention

Cubic feet per minute

Code of Federal Regulations

Confidence interval

Endotoxin units

Heat recovery unit

Heating, ventilation, and air-conditioning

Not detected

National Institute for Occupational Safety and Health

Occupational exposure limit

Occupational Safety and Health Administration

Permissible exposure limit

Parts per million

Prevalence ratio

Recommended exposure limit

Relative humidity

Short-term exposure limit

Threshold limit value

Time-weighted average

Variable frequency drive

Workplace environmental exposure level

World Health Organization 
This page left intentionally blank 


\section{Introduction}

The Health Hazard Evaluation Program received a request for assistance from officials at a local health department in August 2015. They became concerned about reports of eye and nose irritation, difficulty breathing, cough, and vomiting among employees at an indoor waterpark resort during an investigation of complaints from waterpark resort patrons. The local health department asked the Health Hazard Evaluation Program to evaluate symptoms and exposures to chlorine and disinfection byproducts among employees at the waterpark resort. We visited the facility in August 2015 and January 2016. We sent letters to the employer and employees with preliminary findings and recommendations in September 2015 and January 2016.

\section{Background}

\section{Chlorine and Disinfection Byproducts}

Chlorine is the most common chemical used to disinfect the water in recreational water venues such as swimming pools, hot tubs or spas, and waterparks worldwide [WHO 2006]. Chlorine reacts with chemicals from swimmers' bodies such as dirt, skin cells, sweat, feces, urine, and body care products to form chemicals that are referred to as disinfection byproducts. Many types of disinfection byproducts can be found in recreational water venues; two of the more-studied types are trihalomethanes and chloramines (Appendix B). Disinfection byproducts have been associated with eye and respiratory tract symptoms in people who work in or use recreational water venues [Fantuzzi et al. 2010; Jacobs et al. 2007; Massin et al. 1998; NIOSH 2010b; Parrat et al. 2012; Villanueva et al. 2015].

\section{Process Description}

At the time of our evaluation, the waterpark resort had been operated by the same company since 2013 and had 112 employees. The resort was open 24 hours a day, 7 days a week yearround, but the waterpark was closed on Monday-Thursday from Labor Day to Memorial Day, except for holidays. For example, in the 4 weeks prior to our visit, the waterpark was open each day for 5 to 14 hours over winter break. Waterpark operating hours varied depending on the season and day of the week. During our January 2016 visit over the Martin Luther King, Jr. holiday weekend, the waterpark was open between 5 and 11 hours per day.

The waterpark features consisted of the Kiddie Korral (children's activity pool); activity pool; the Rain Fortress with splash area and bucket (Figure 1); the Slide Tower with four waterslides: Ambush Alley and Raging Bull (tube slides); Black Out Pass (funnel slide into the Lazy River); Cowboy Creek (inner tube with tumble buckets or rapids); the Shoot Out Racer (mat racer); and a whirlpool spa. The state Department of Agriculture, Division of Amusement Ride Safety regulates the waterpark features, and the local health department regulates the whirlpool spa. The water temperatures for the features reportedly were kept between 83 degrees Fahrenheit $\left({ }^{\circ} \mathrm{F}\right)$ and $86^{\circ} \mathrm{F}$; the whirlpool spa reportedly was kept at a 
higher temperature (about $100^{\circ} \mathrm{F}$ ). A large two-story mechanical area, which contained the ventilation units, surge tanks, and pumps, was located in an attached structure on the east side of the waterpark.

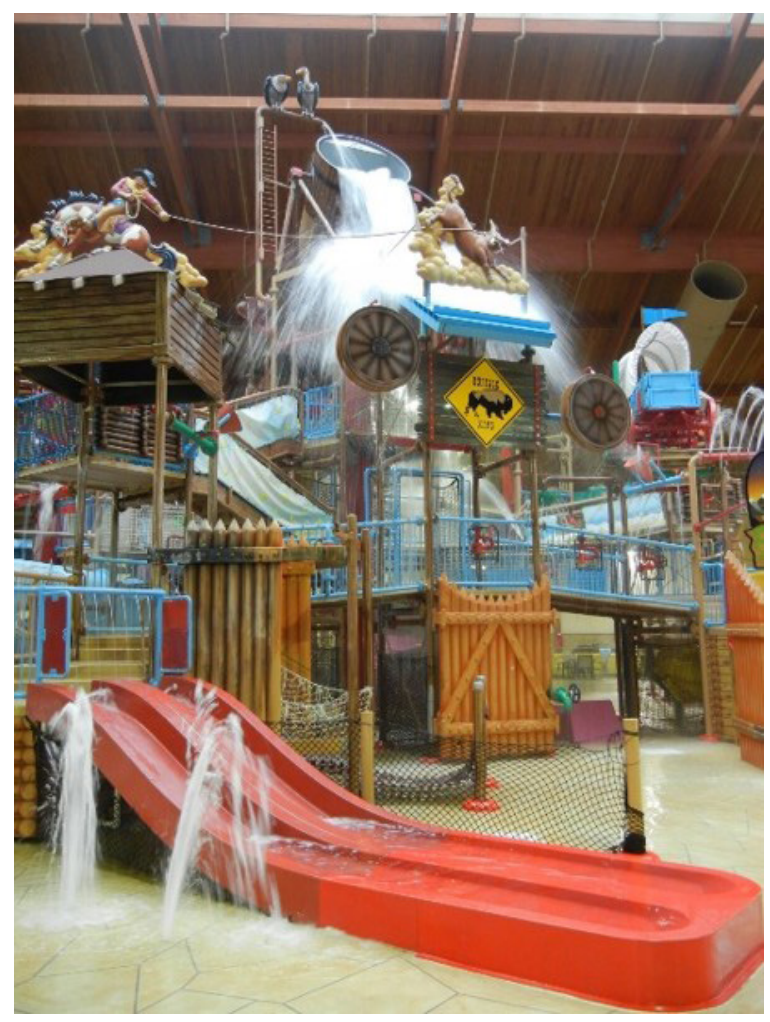

Figure 1. Water spraying in the Rain Fortress feature of the waterpark. Photo by $\mathrm{NIOSH}$.

The aquatics department personnel included lifeguards, greeters, and supervisors. At the time of our evaluation, the department had approximately 60 employees, including many under 18 years of age. Approximately half of aquatics department members were seasonal workers.

Lifeguards rotated through the different water features at 30-minute intervals. Some stations required being submerged in water up to thigh level. Aquatics department employees were also responsible for removing formed fecal matter from the water using scoopers; cleaning up vomitus, unformed feces, and blood in the waterpark; and providing first aid and supplemental oxygen to patrons. They also set up furniture and trash cans before the waterpark opened each day and stacked the furniture after the waterpark closed. Greeters checked wristbands to ensure that guests had paid for waterpark access and welcomed guests at the entrance of the waterpark. Five waterpark maintenance staff members were in charge of chemical monitoring of the water systems and features and operating the ventilation systems. They also checked each waterpark feature for safety hazards such as rough or sharp edges and ensured that the netting, lashings, and cables were attached and secure and that the drains functioned properly.

At the time of the evaluation, the waterpark used calcium hypochlorite solution as the main disinfection agent. Muriatic acid (also called hydrochloric acid) was used to control $\mathrm{pH}$. 
Sodium sulfate was occasionally used to control water conditions. The waterpark had several surge tanks, located in the mechanical area, which serviced the pools. Water pumped from the surge tanks went through strainer baskets that were emptied at least twice daily by maintenance staff. The water then went through sand filtration and ultraviolet disinfection systems before going to an automated chemical controller system that monitored and maintained the appropriate $\mathrm{pH}$ and free chlorine levels.

The water in the features was completely changed every 2 weeks using the city public water supply. Maintenance staff took water samples from valves in the pump room maintenance workstation located in the mechanical area and used titration techniques to test the free chlorine levels and $\mathrm{pH}$ of water from the Lazy River, Rain Fortress, Kiddie Korral, and whirlpool spa features. This water testing was done before the waterpark opened and every 2 hours when the waterpark was operational. According to standard operating procedures, the acceptable range was 3.0-5.0 parts per million ( $\mathrm{ppm}$ ) for free chlorine, 0-0.2 ppm for combined chlorine, and 7.4-7.6 for $\mathrm{pH}$. These chemical concentrations were adjusted as needed and retested after the appropriate chemical was added. Maintenance staff also collected water samples at seven water features in the waterpark every 3 hours and tested these samples for free chlorine and $\mathrm{pH}$. In addition, aquatics department supervisors tested the water at the different features for free chlorine and $\mathrm{pH}$ levels hourly when the park was open.

In addition to the waterpark, the resort had a hotel, conference center, restaurant, bar, gift shop, arcade, concession stand, and an office area behind the hotel front desk. The concession stand, including its kitchen, was located within the waterpark. The waterpark and concession stand were separated from the rest of the facility by walls and doors and had a separate ventilation system. The arcade had private party rooms with doors that opened into the waterpark. Because the restaurant was operated by another company, we did not include it in our evaluation.

Approximately 50 employees worked in the non-waterpark areas of the resort. They included hotel housekeepers, front desk staff, a maintenance manager, bartenders, gift shop attendants, arcade attendants, managers, office staff, and security guards. Maintenance staff collected and tested water samples at seven water features in the waterpark, but spent most of their time in the mechanical area adjacent to the park or other areas of the resort. Occasionally, hotel front desk staff and managers showed the waterpark to potential guests. Security guards passed through the waterpark when they made their rounds through the facility.

\section{Heating, Ventilation, and Air-conditioning System Description}

At the time of the evaluation, the waterpark was serviced by six large Menerga type 3432 heating, ventilation, and air-conditioning (HVAC) units in the upper mechanical area. Four of these heat recovery units (HRUs $1,2,5,6$ ) were designed to provide a maximum air supply rate of 18,830 cubic feet per minute (cfm) per HRU to the waterpark. The remaining two units (HRUs 3 and 4) could provide a maximum air supply rate of 14,710 cfm each. All units used metal supply and return ducts. Each unit had a supply and return air fan. Each unit could pull in outdoor air and exhaust air to the outside through stacks on the roof. The units also 
supplied conditioned air to the pool areas and recovered heat from the return air. The units could operate in different modes depending on outside environmental conditions and control set points. These different modes reportedly introduced between 33\% (67\% recirculation of air) and 100\% outdoor air (no recirculation) based on the outside ambient temperature.

Air was supplied to the waterpark through two main 60 -inch diameter trunk lines that ran along the ceiling of the facility (Figure 2). The air supply ducts were outfitted with drum type diffusers that provided directional airflow. Supply air main \#1 was fed by HRUs 1, 2, and 3 and ran along the north wall of the waterpark adjacent to the whirlpool and children's activity pool before turning and running along the west wall of the waterpark. Most supply diffusers on this trunk line were designed to provide 2,120 cfm, with the exception of a branch off the main trunk line near the Rain Fortress, which had four separate 900-cfm supply air diffusers (43 feet above the deck). Supply air main \#2 was fed by HRUs 4, 5, and 6. It ran along the east wall of the waterpark and serviced the Lazy River and the mat racer. The main trunk line duct diameter was stepped down in size as it extended further from the fan unit to provide balancing of airflow through the outermost air supply diffusers. Two return air intakes $\left(\mathrm{L}-4,120^{\prime \prime} \times 56^{\prime \prime}\right.$ and L-5, 120" $\left.\times 40^{\prime \prime}\right)$ were located at deck height along the west wall of the mechanical area adjacent to the mat racer slides. Two additional return air intakes were located approximately 36 feet above the pool deck, closer to the north end of the waterpark (near the Slide Tower entrance).

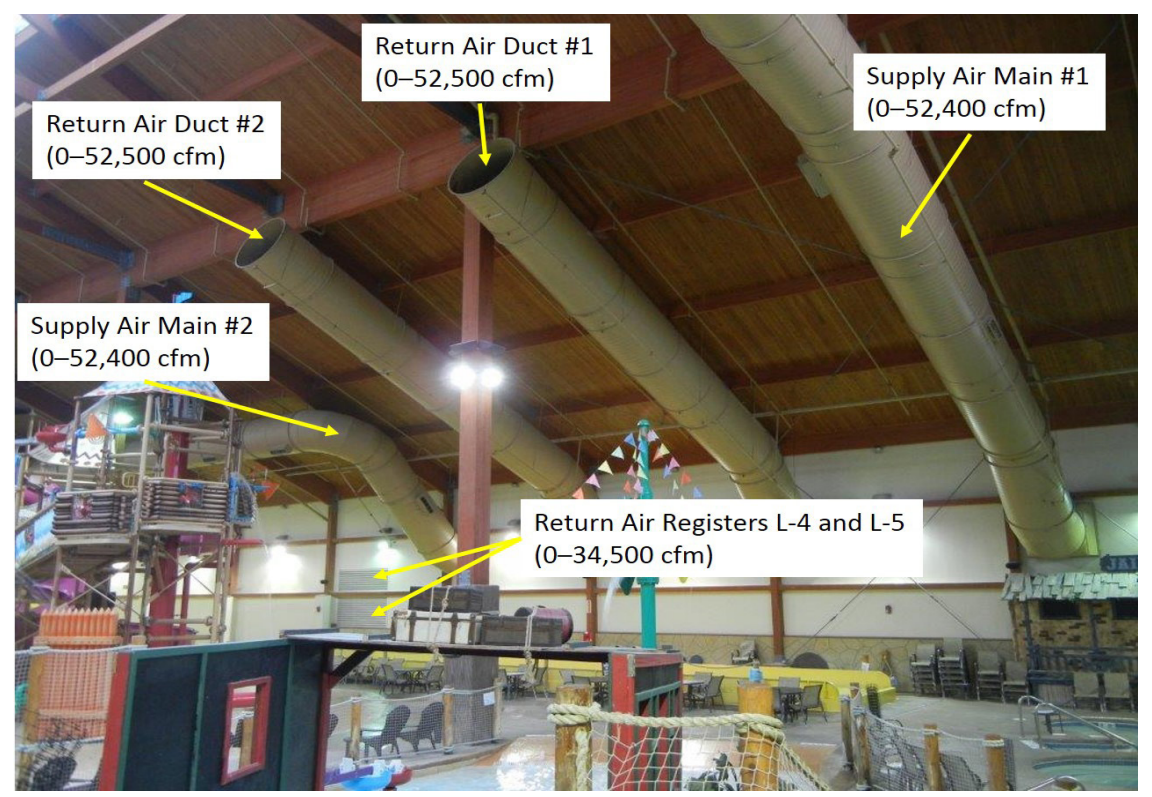

Figure 2. Location of return air registers, return air ducts, and supply air ducts inside the waterpark. Photo by NIOSH. 


\section{Methods}

The objectives of our evaluation were to assess the prevalence and determine the etiologies of work-related symptoms of employees.

\section{Initial Visit}

We met with employer and employee representatives and walked through the facility to become familiar with facility layout and typical work activities. We reviewed blueprints of the ventilation systems and inspected ventilation units and outdoor air intakes. We also reviewed disinfection policies and water chemistry testing procedures.

We discussed work history and practices, symptoms, and workplace safety and health concerns during confidential medical interviews with employees. Of the 66 employees working during our visit, 21 (32\%) were under 18 years of age. Because of the need for parental consent, we did not include them in our interviews. After excluding those under age 18, we invited all 14 employees in the aquatics department and a convenience sample of 14 employees in other departments, including three maintenance employees, to participate.

We defined waterpark employees as employees in the aquatics department (lifeguards, greeters, and supervisors) and the concession stand located within the waterpark because their job duties required being in the waterpark for most of their working hours. Aquatic department members were exposed to pool water, but concession stand and non-waterpark employees likely did not have exposure to pool water. We defined all other employees, including maintenance employees, as non-waterpark employees. Although maintenance employees and some other employees spent time in the waterpark, they had more flexibility about when and how much time they spent in the waterpark. For the interviews, we considered a symptom to be work-related if a participant reported experiencing the symptom at work and the symptom improved while away from work. We summarized descriptive statistics for demographic, work, and health information.

\section{Second Visit}

Our work included (1) administration of questionnaires to employees, (2) measurement of area air concentrations of chlorine, chloroform, and endotoxins, (3) review of company water test and disinfection procedures, (4) microbial and chemical analyses of water samples, (5) evaluation of indoor environmental quality, and (6) evaluation of the waterpark HVAC.

\section{Employee Questionnaires}

We invited all employees working during our site visit to fill out a questionnaire that asked about work history and practices, symptoms related to work over the past 4 weeks, medical history, and demographic information (main questionnaire). At the end of each work day, we also asked employees to fill out a brief questionnaire about any symptoms experienced, number of hours worked, and work activities for each of the 3 days of our site visit (daily questionnaire). All participation was voluntary. We obtained written informed consent for participation from the parents or legal guardians of all employees under the age of 18 years. 
We summarized descriptive statistics for demographic, work, and health information. We defined waterpark employees as employees in the aquatics department (lifeguards, greeters, and supervisors) and in the concession stand located in the waterpark on the basis of the employee roster the employer supplied. We defined all other employees as non-waterpark employees. We asked about symptoms experienced in the previous 4 weeks. We considered a symptom to be work-related if a participant reported the symptom started at work and improved when away from work. For the daily questionnaires, we considered a symptom to be work-related if it started at work that day. We asked participants to not include symptoms associated with a cold or respiratory infection.

We compared the characteristics of waterpark and non-waterpark employees surveyed using the Mann-Whitney $U$ test for continuous variables and the $\chi^{2}$ test for categorical variables. We compared the proportion of waterpark and non-waterpark employees who reported a rash on the questionnaire using Fisher's exact test. All statistical tests were two-sided, and statistical significance was set at $P<0.05$.

We defined a case as an employee with three or more of the following work-related symptoms in the past 4 weeks: cough, wheeze, shortness of breath, chest tightness, nose irritation, eye irritation, and sore throat. We calculated the prevalence ratio (PR) and 95\% confidence interval (CI) for meeting the case definition by comparing the prevalence rate for waterpark employees to that for non-waterpark employees. We used Epi Info version 7.2.0.1 to perform statistical analyses.

\section{Air Sampling and Analysis}

We collected area air samples at six fixed locations in the waterpark, outside, in the concession stand, and in the arcade. We moved one of the sampling locations in the waterpark from the Lazy River on day 1 to the towel service/party room for days 2 and 3 because patrons kept handling the sampling equipment. We did not collect personal air samples on waterpark employees because the sampling equipment attached to the lifeguards could interfere with their jobs. Also, if the equipment got wet, the sample results would not be valid.

We collected 27 area air samples for endotoxins. Endotoxins are lipopolysaccharide compounds that may be released by the outer cell walls of Gram-negative bacteria when the bacteria die or multiply. Gram-negative bacteria are commonly associated with the human digestive tract and are an indicator of bather load. We used personal air-sampling pumps calibrated at 2 liters per minute to collect the samples onto 0.45 -micrometer-pore-size polycarbonate filters in an endotoxin-free three-piece 37-millimeter closed-face cassette. We analyzed the samples for endotoxin content with the kinetic-chromogenic procedure using the limulus amebocyte lysate assay [Cambrex 2005]. The limit of detection was 0.50 endotoxin unit (EU) per sample.

We used the National Institute for Occupational Safety and Health (NIOSH) method 6011 to collect and analyze 26 area air samples for chlorine. [NIOSH 2017].

We measured levels of chloroform, the most abundant trihalomethane disinfection byproduct 
found in the air in pools [Tardif et al. 2015]. NIOSH does not have a valid air sampling method for chloramines, the other significant disinfection byproduct. Past NIOSH chloramine exposure assessments used a sampling and analytical method reported in the scientific literature [Héry et al. 1995]. Several deficiencies in the NIOSH assessments were noted, including a lack of consistency in the limits of detection and limits of quantitation between investigations and the inability to produce a laboratory chloramine standard against which results can be compared [NIOSH 2012]. We collected and analyzed 119 area air samples for chloroform using charcoal tubes with SKC pocket pumps calibrated at 0.1 liter per minute according to NIOSH Method 1003 [NIOSH 2017]. We switched charcoal tubes out every 2 hours to avoid breakthrough, which can occur in a high humidity environment. We combined samples to provide full-day exposure concentrations.

\section{Water Sampling and Analysis for Legionella, Mycobacteria, and Total and Free Chlorine}

We collected water samples for analysis of Legionella and mycobacteria from various locations in the whirlpool spa. We collected 25 samples (250 milliliters per sample) within a half hour time frame in sterile bottles containing sodium thiosulfate prepared by the contract laboratory according to the Centers for Disease Control and Prevention (CDC) procedure [CDC 2005]. We shipped the samples cold to the contract laboratory. Two bottles broke in transport but the other bottles remained sealed; the samples were combined to make five 1-liter samples and one 0.75-liter sample for analysis according to CDC laboratory methods [CDC 2005]. The contract laboratory first concentrated the water samples using a centrifuge. For Legionella analysis, some of the concentrate was plated on buffered charcoal yeast extract agar containing $0.1 \%$ alpha-ketoglutarate and cultured for 7 to 10 days according to CDC laboratory methods [CDC 2005]. For mycobacteria analysis, some of the concentrate from each composite sample was placed in a Bactech system, which was monitored for growth weekly for 6 weeks. Simultaneously, the contract laboratory plated some of the concentrate from each composite sample on Middlebrook 7H10 agar and cultured the plates for 6 weeks to look for mycobacteria.

We performed water testing for total and free chlorine with a standard color-matching Taylor Technologies Inc. DPD test kit.

\section{Indoor Environmental Quality Parameters}

We monitored temperature, relative humidity $(\mathrm{RH})$, and carbon dioxide levels using TSI Q-Trak ${ }^{\mathrm{TM}}$ indoor air quality monitors inside the waterpark, in the arcade and gift shop outside of the waterpark, and outdoors. On days 2 and 3, we measured temperature and RH in additional locations in the waterpark using $\mathrm{HOBO}{ }^{\circledR} \mathrm{H} 8$ Pro series data loggers because of the high humidity levels that were found on day 1.

\section{Ductwork Material Bulk Sample Analysis}

We observed crystalline material hanging from the ventilation system ductwork in the area where the plenums for recirculated and outside air joined. We submitted a bulk sample of this material to the analytical laboratory for identification. 


\section{Heating, Ventilation, and Air-conditioning System Evaluation}

We used blueprints to estimate the square footage of pool and deck area and the overall air supply and return flow rates. When possible, we measured air velocity at HRU supply plenums to estimate the supply airflow to the waterpark. The heights of the supply and return air registers were measured using a Robert Bosch Tool Corporation laser distance measurer. In addition, we used a TSI/Alnor EBT 730 microanemometer with a model 960 thermoanemometer probe attachment to measure air velocity in the outside air intake plenum. We took measurements with and without the air filter in place to assess the effect of filter pressure drop on airflow rate through the unit. On the basis of the estimated square footage of the waterpark, we compared the air supply rate of the waterpark to consensus standards [ASHRAE 2015, 2016; CDC 2016f]. We released nontoxic smoke at all doors between the waterpark and hotel and between the waterpark and all of the party rooms to assess whether air was moving out of or into the pool area from adjacent rooms.

\section{Review of Waterpark Records}

We reviewed incident reports from the waterpark from January 31, 2015, to January 17, 2016 , for date, time, and type of event. We also reviewed fecal accident reports from January 1, 2015, to January 17, 2016.

\section{Results}

\section{Employee Interviews}

We interviewed $28(62 \%)$ employees who were 18 years of age or older during our initial visit in August 2015. The median age of the interviewed employees was 22 years (range: 1861 years); half were male. Fifteen employees (64\%) were waterpark employees, consisting of 14 aquatics department members and 1 concession stand employee. The 13 non-waterpark employees consisted of maintenance staff, an arcade attendant, a bartender, housekeeping staff, hotel front desk staff, office staff, and managers. Eight employees (29\%) were seasonal employees, all of whom were waterpark employees. The median number of hours worked per week was 40 (range: 16-60 hours). Five (24\%) employees, four waterpark employees and one maintenance employee, reported handling chemicals used in the water.

Twenty employees (71\%) reported having work-related symptoms, defined as symptoms experienced at work that improved while away from work, from the beginning of the summer season to the day of the interview in August (approximately 3 months). Waterpark and non-waterpark employees reported work-related symptoms. Figure 3 summarizes the work-related symptoms reported by the employees interviewed. The most commonly reported symptoms were eye irritation (68\%), followed by cough $(61 \%)$ and nose irritation (54\%). Five employees (18\%) also reported having a rash during this time period. Four of 20 employees with at least one work-related symptom (25\%) reported taking a median of 2.5 days (range: 1-3.5 days) off work because of symptoms.

On the basis of these findings, we decided that further evaluation focusing on respiratory and eye symptoms was warranted. 


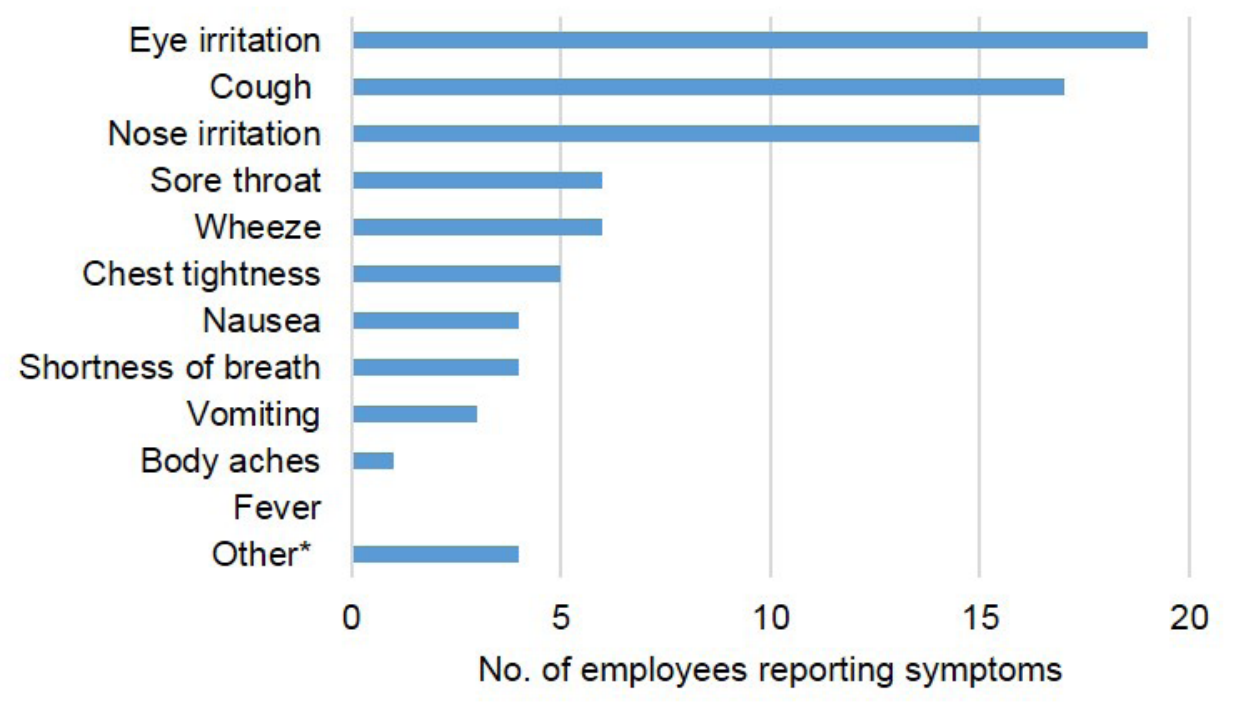

*Skin irritation, sneezing, dizziness, and headache were each reported by one employee

Figure 3. Number of employees reporting symptoms out of 28 employees interviewed.

\section{Main Questionnaire}

\section{Demographic, Work, and Health Characteristics of Survey Respondents}

In total, 91 (81\%) of 112 employees who worked during our January 2016 site visit completed the main questionnaire. Of the 48 employees under 18 years of age, $28(58 \%)$ completed a main questionnaire, compared with 62 of $64(98 \%)$ employees aged 18 years or older. The median age of employees who completed a questionnaire was 19 years (range: 15-65 years); 47 (52\%) were male.

Employees who completed the main questionnaire reported working at the waterpark resort for a median of 10 months (range: 3 weeks-12.5 years). Few were seasonal employees (n $=5 ; 6 \%$ ). Employees worked a median of 80 hours (range: 14-240 hours) over the past 4 weeks, which included winter break when the waterpark was open every day.

By job title, 45 (49\%) were categorized as waterpark employees. Table 1 shows the job title group of the employees who completed the main questionnaire by age group. Most respondents younger than 18 years were waterpark employees (93\%). However, 14 nonwaterpark employees reported being in the waterpark on a typical work day in the past 4 weeks, for a total of 59 employees who reported spending any time in the waterpark on a typical work day. These included employees in the front desk or office area $(\mathrm{n}=$ $5)$, maintenance staff $(n=5)$, security personnel $(n=3)$, and housekeeping $\operatorname{staff}(n=1)$. Maintenance employees reported spending a median of 6 hours (range: $2.5-8$ hours) in the waterpark on a typical work day. However, upon further questioning, we learned that most of their time in the waterpark is spent in the adjacent mechanical area which is not ventilated by the waterpark HVAC units. The other nine employees reported spending a median of 1 hour (range: 10 minutes-3 hours) in the waterpark on a typical work day. 
Table 1. Job title group of employees surveyed by age group

\begin{tabular}{lcc}
\hline Job title group & $\begin{array}{c}\text { No. (\%) } \\
\text { employees aged } \\
\geq 18 \text { years } \\
\mathrm{N}=63\end{array}$ & $\begin{array}{c}\text { No. }(\%) \\
\text { employees aged } \\
<18 \text { years } \\
\mathrm{N}=28\end{array}$ \\
\hline Waterpark & $19(30)$ & $26(93)$ \\
Aquatics & $17(27)$ & $22(79)$ \\
Supervisor & $5(8)$ & $1(4)$ \\
Lifeguard or greeter & $12(19)$ & $21(75)$ \\
Concession stand & $2(3)$ & $4(14)$ \\
Non-waterpark & $44(70)$ & $2(7)$ \\
Front desk/lobby & $21(33)$ & $0(0)$ \\
Maintenance & $6(10)$ & $0(0)$ \\
Arcade & $5(8)$ & $0(0)$ \\
Gift shop & $2(3)$ & $2(7)$ \\
Housekeeping & $4(6)$ & $0(0)$ \\
Security & $4(6)$ & $0(0)$ \\
Bar & $2(3)$ & $0(0)$ \\
\hline
\end{tabular}

Table 2 shows the demographic and work characteristics of the employees surveyed. In general, waterpark employees were younger and had worked at the waterpark resort for a shorter duration than non-waterpark employees. The sex distribution and number of hours worked over the past 4 weeks were similar between the two groups.

Table 2. Demographic and work characteristics of employees surveyed

\begin{tabular}{lccc}
\hline Characteristic & $\begin{array}{c}\text { Waterpark } \\
\text { employees } \\
\mathrm{N}=45\end{array}$ & $\begin{array}{c}\text { Non-waterpark } \\
\text { employees } \\
\mathrm{N}=46\end{array}$ & $P$ value \\
\hline Age < 18 years; no. (\%) & $26(58)$ & $2(4)$ & $<0.001$ \\
Male sex; no. (\%) & $23(51)$ & $24(52)$ & 0.92 \\
Job tenure, months; median (range) & $7(<1-78)$ & $14(<1-150)$ & 0.005 \\
$\begin{array}{l}\text { Hours worked in a typical day over } \\
\text { past 4 weeks; median (range) }\end{array}$ & $72(15-204)$ & $86(14-240)$ & 0.24 \\
\hline
\end{tabular}

Of the 59 employees who reported spending any time in the waterpark on a typical work day, $11(19 \%)$ reported handling the chemicals used in the water in the past 4 weeks, including 5 maintenance staff members, 4 aquatics department supervisors, and 2 lifeguards. Only lifeguards $(n=14)$ and aquatics department supervisors $(n=5)$ reported handling vomitus, stool, or blood in the water in the past 4 weeks.

Thirteen (14\%) of 91 employees reported currently having asthma that was diagnosed by a healthcare provider. Two of the 13 reported that they did not have asthma before working at the waterpark resort; both were waterpark employees. Twelve (92\%) of the 13 employees with current asthma reported that their asthma seemed worse at work. 
Twenty-three (25\%) employees reported having a history of hay fever or other seasonal allergies. Ten (11\%) employees reported having a history of eczema or atopic dermatitis. Thirty-two (35\%) employees had atopy, defined as current asthma, hay fever, or other seasonal allergies, and/or eczema or atopic dermatitis. Eleven (12\%) employees were current smokers.

\section{Work-related Symptoms}

Regarding work-related symptoms, 37 (82\%) waterpark employees and 11 (24\%) non-waterpark employees (including two members of the maintenance staff) reported experiencing at least one work-related symptom during the past 4 weeks. Among waterpark employees, the most commonly reported work-related symptom was eye irritation $(62 \%)$, followed by cough (56\%) and nose irritation (51\%). Table 3 shows the number and percentage of waterpark and non-waterpark employees reporting each work-related symptom.

Table 3. Work-related symptoms* reported by waterpark and non-waterpark employees over the past 4 weeks

\begin{tabular}{lcc}
\hline Symptom & $\begin{array}{c}\text { No. (\%) of } \\
\text { waterpark } \\
\text { employees } \\
\mathrm{N}=45\end{array}$ & $\begin{array}{c}\text { No. (\%) of } \\
\text { non-waterpark } \\
\text { employees } \\
\mathrm{N}=46\end{array}$ \\
\hline Any symptom & $37(82)$ & $11(24)$ \\
Eye irritation & $28(62)$ & $6(13)$ \\
Cough & $25(56)$ & $3(7)$ \\
Nose irritation & $23(51)$ & $3(7)$ \\
Wheeze & $19(42)$ & $2(4)$ \\
Shortness of breath & $14(31)$ & $3(7)$ \\
Chest tightness & $14(31)$ & $3(7)$ \\
Sore throat & $4(9)$ & $3(7)$ \\
\hline
\end{tabular}

*Began while at work and improved away from work, not associated with a cold or respiratory infection.

Eight waterpark employees (18\%) and one non-waterpark employee (2\%) reported having a rash over the past 4 weeks $(P=0.02)$. All nine employees thought that their rash was related to work. Of the eight waterpark employees with a rash, one worked in the concession stand, six were lifeguards, and one was an aquatics supervisor. The seven aquatics department employees reported spending time in the water. None reported handling chemicals used in the water. Among the seven employees who spent time in the water, the most commonly reported area of the body with rash was the legs $(n=5)$, followed by arms $(n=2)$, face $(n=2)$, hands $(\mathrm{n}=1)$, and neck $(\mathrm{n}=1)$. The sole non-waterpark employee who reported having a rash worked in housekeeping and did not spend time in the water.

Of the 49 employees with a rash, at least one work-related symptom, or both, $12(24 \%)$ had taken time off work for these reasons in the past 4 weeks. The median time off work was 2 days (range: $1-5$ days). Seven employees (14\%) sought care from a healthcare provider for a work-related symptom or rash in the last 4 weeks. 
Of the 91 respondents, 29 (32\%) met the case definition, including 24 waterpark employees and five non-waterpark employees. One of the five non-waterpark employees who met the case definition was a maintenance employee. Waterpark employees were 4.91 times more likely to meet the case definition than non-waterpark employees $(95 \% \mathrm{CI}=(2.05-11.73))$.

\section{Daily Questionnaires}

Of the 91 employees who completed a main questionnaire, $86(95 \%)$ completed at least one daily questionnaire. On day 1, $70(72 \%)$ of 97 employees who were working filled out a daily questionnaire. The participation rate was 77\% (59 of 77 employees) on day 2 and $65 \%$ (35 of 54 employees) on day 3.

The median number of hours worked reported by all employees was 7.5 (range: 2-12.5) on day 1, 7.5 (range: 2.6-13) on day 2, and 8.5 (range: 4-12) on day 3. Ten waterpark employees reported working 12 or more hours on day 1 and eight waterpark employees reported working 12 or more hours on day 2. No waterpark employees worked 12 or more hours on day 3. Few respondents reported handling vomitus, stool, or blood (0-3 employees) or chemicals used in the water ( $0-2$ employees) on any of the 3 days.

On day 1, 38 waterpark employees and 32 non-waterpark employees completed a daily questionnaire, as did 32 waterpark employees and 27 non-waterpark employees on day 2, and 22 waterpark employees and 13 non-waterpark employees on day 3 . Table 4 summarizes the symptoms reported by waterpark employees by day and the corresponding daily bather load. We used the number of wristbands distributed each day to estimate bather load. The most common symptom was eye irritation on day $1(61 \%)$ and day $2(69 \%)$ and cough on day 3 $(55 \%)$. One waterpark employee reported going to the emergency department after work on day 1 for evaluation of severe eye irritation. The percentage of waterpark employees who reported symptoms did not appear to vary with bather load.

Table 4. Bather load and work-related ${ }^{*}$ symptoms reported by waterpark employees by day

\begin{tabular}{lccc}
\hline & Day 1 & Day 2 & Day 3 \\
\hline Bather load & 854 & 489 & 184 \\
No. of waterpark employees completing questionnaires & 38 & 32 & 22 \\
Work-related symptoms, no. of employees (\%) & & & \\
$\quad$ Any work-related symptom & $25(66)$ & $25(78)$ & $15(68)$ \\
Eye irritation & $23(61)$ & $22(69)$ & $9(41)$ \\
Cough & $20(53)$ & $20(63)$ & $12(55)$ \\
Nose irritation & $17(45)$ & $15(47)$ & $9(41)$ \\
Wheeze & $5(13)$ & $5(16)$ & $1(5)$ \\
Shortness of breath & $5(13)$ & $6(19)$ & $1(5)$ \\
Sore throat & $3(8)$ & $2(6)$ & $0(0)$ \\
\hline
\end{tabular}

*Started at work on that day, not associated with a cold or respiratory infection 


\section{Sampling Results}

\section{Area Air Samples}

Endotoxin concentrations in air samples are reported in Appendix A, Table A1. Endotoxin concentrations in the pool area ranged from not detected to $68 \mathrm{EU} / \mathrm{m}^{3}$. Endotoxin concentrations in the arcade and outdoors ranged from not detected to $4.5 \mathrm{EU} / \mathrm{m}^{3}$. The highest endotoxin concentrations were near the Lazy River feature. Overall, the highest detected concentrations occurred on day 1 of monitoring, which had the highest bather load.

Chlorine concentrations in area air samples are reported in Appendix A, Table A2. The air concentrations for chlorine ranged from not detected to $0.092 \mathrm{ppm}$, well below occupational exposure limits (OELs). The highest concentration was found by the Lazy River feature on day 2 of monitoring. The lowest concentrations were found in the concession stand and arcade. No chlorine was detected in the two outdoor air samples.

Chloroform concentrations in air samples are reported in Appendix A, Table A3. The chloroform concentrations in the pool area ranged from not detected to $0.00054 \mathrm{ppm}$, well below OELs.

\section{Water Sampling for Legionella, Mycobacteria, and Total and Free Chlorine}

No Legionella or mycobacteria were found in any of the water samples we collected.

Water chemistry results are shown in Appendix A, Table 4. According to the waterpark internal maintenance guidance document, free chlorine should range from 3 to $5 \mathrm{ppm}$, and combined chlorine should range from 0 to $0.2 \mathrm{ppm}$. Combined chlorine can be used as an indication of the presence of chloramines in the water [CDC 2016b]. On day 1 of monitoring, the free chlorine concentrations were below the waterpark's recommended levels in three of the four monitored features in the afternoon (whirlpool spa, Lazy River, and Kiddie Korral). On day 2 of monitoring, the free chlorine concentrations were below recommended levels in the Lazy River and activity pool in the morning and at the slide in the afternoon. The free chlorine concentration was above recommended levels in the whirlpool spa in the afternoon. On day 3 of monitoring, the slide, whirlpool spa, and Rain Fortress had low free chlorine concentrations in both the morning and afternoon. In addition, the Kiddie Korral had low concentrations in the morning, and the activity pool had low concentrations in the afternoon.

The combined chlorine results show that chloramines were present in the water on all three days of the evaluation. On day 1 of monitoring, the combined chlorine concentrations exceeded the waterpark's internal recommended levels in all four monitored features in the afternoon (slide, whirlpool spa, Lazy River, and Kiddie Korral). On day 2 of monitoring, the combined chlorine concentrations were above recommended levels in the slide, whirlpool spa, Rain Fortress, and activity pool. On day 3 of monitoring, the combined chlorine concentrations were above recommended levels in the whirlpool spa and Rain Fortress. The highest concentration was found in the whirlpool spa $(0.8 \mathrm{ppm})$ on the afternoon of day 3 . 


\section{Indoor Environmental Quality Parameters}

Air temperature, RH, and carbon dioxide levels measured by Q-Trak monitors are shown in Appendix A, Table A5, and air temperature and $\mathrm{RH}$ results measured by HOBOs are presented in Appendix A, Table A6. The Model Aquatic Health Code recommends that waterpark management comply with the ASHRAE and the American National Standards Institute (ANSI) publication ANSI/ASHRAE Standard 62.1-2016, Ventilation for Acceptable Indoor Air Quality [ASHRAE 2016] and ASHRAE Handbook - Heating, Ventilating, and Air-Conditioning Applications [ASHRAE 2015] for temperature, RH, and carbon dioxide levels. We could only measure outdoor conditions on day 1 because outdoor air temperatures were below freezing for the rest of the evaluation. The temperatures below freezing were outside of the sampling equipment's functional range. Air temperature taken across locations in the waterpark ranged between $51.8^{\circ} \mathrm{F}$ and $78.6^{\circ} \mathrm{F}$, with the lowest temperature under the stairs at the Lazy River and the highest temperature in the whirlpool spa area. ASHRAE recommends that the air temperatures in pool facilities within hotels should be between $82^{\circ} \mathrm{F}$ and $85^{\circ} \mathrm{F}$, and for whirlpool/spa areas to be between $80^{\circ} \mathrm{F}$ and $85^{\circ} \mathrm{F}$ [ASHRAE 2015]. Air temperature in the waterpark was below the ASHRAE guidelines. The concession stand temperatures for day 2 and day 3 ranged from a low of $60.1^{\circ} \mathrm{F}$ to a high of $71.8^{\circ} \mathrm{F}$. The average air temperatures in the arcade and gift shop ranged from $64.7^{\circ} \mathrm{F}$ to $70.0^{\circ} \mathrm{F}$. Assuming slow air movement and $50 \% \mathrm{RH}$, the operative temperatures recommended by ANSI/ASHRAE range from $68^{\circ} \mathrm{F}$ to $76^{\circ} \mathrm{F}$ in the winter [ASHRAE 2016]. These temperatures were either below or at the lower end of the ASHRAE guidelines for retail and public areas in hotels [ASHRAE 2016]. The temperatures inside were lower each day, corresponding to decreasing outdoor temperatures.

$\mathrm{RH}$ levels across waterpark locations ranged from $24 \%$ to $100 \%$ over the three days. $\mathrm{RH}$ levels were $100 \%$ on day 1 at the Lazy River and whirlpool spa and on day 3 at the whirlpool spa. ASHRAE recommends that the RH in pool facilities for hotels and in whirlpool/ spa areas be between 50\% and 60\% [ASHRAE 2015]. ANSI/ASHRAE recommends that RH be maintained at or below $65 \%$ in all indoor environments [ANSI/ASHRAE 2016]. The waterpark RH levels did not meet these guidelines. Excessive humidity can promote the excessive growth of microorganisms and dust mites. The RH was highest on day 1 of monitoring when the park was open the longest and more people were present. Over the three days, RH levels ranged from $5.1 \%$ to $48.5 \%$ in the arcade and from $10.1 \%$ to $95.7 \%$ in the gift shop. We were not able to identify the source of the peak exposure in the gift shop.

Carbon dioxide is a normal part of exhaled breath. Its concentration can be used to determine if enough outdoor air is being supplied to keep odors to an acceptable level. Indoor carbon dioxide concentrations no greater than $700 \mathrm{ppm}$ above outdoor carbon dioxide concentrations will satisfy about $80 \%$ of occupants [ANSI/ASHRAE 2016]. Carbon dioxide levels in the waterpark ranged from 509 ppm to $1,216 \mathrm{ppm}$ on day $1 ; 461 \mathrm{ppm}$ to $1,158 \mathrm{ppm}$ on day 2; and 363 to $1,455 \mathrm{ppm}$ on day 3 . These levels exceeded the suggested guidelines, which may indicate insufficient ventilation. Carbon dioxide levels in the arcade ranged from $509 \mathrm{ppm}$ to 728 ppm on day 1; 467 ppm to 769 ppm on day 2; and 492 to 644 ppm on day 3, which were within the ASHRAE guidelines. In the gift shop, carbon dioxide levels ranged from $461 \mathrm{ppm}$ to $1,158 \mathrm{ppm}$ on day $1 ; 509 \mathrm{ppm}$ to $1,378 \mathrm{ppm}$ on day 2 ; and 545 to $862 \mathrm{ppm}$ on day 3 ; the 
ASHRAE guidelines were exceeded on day 1 and day 2 .

\section{Ductwork Material Bulk Sample}

The crystalline material was identified as sodium sulfate, which had been used when necessary to lower $\mathrm{pH}$ of the water and control alkalinity in the water features.

\section{Heating, Ventilation, and Air-conditioning System Evaluation}

On the basis of the facility blueprints, the indoor waterpark pool and deck area were estimated to be approximately 40,700 square feet. Of the return air volumes reported on the facility blueprints, approximately $75 \%$ of the return air was pulled from the higher returns, and $25 \%$ was pulled from the lower return air intakes. The facility air change rate was not calculated because outdoor air introduction (flow) rates were not measured. These rates could not be measured without extensive instrumentation and test setup.

A field service report of the system controllers from an electrical service company showed that many of the variable frequency drives (VFDs) that controlled the HRU fan units were nonoperational or nonrepairable. The report stated that the technician was able to get airflows in HRUs 1-5 to operational status, but HRU 6 was inoperable. We observed that many of the supply and return fans were not operating during our visit (Appendix A, Table A7). The facility was awaiting a quote from the electrical service company for replacement or repair of the inoperable VFD units.

When we spoke with the maintenance staff about intake air filtration, we learned that the original air filter supplied with each unit had been replaced with a cleanable pocket-type filter. The Viskon-Aire 428 medium efficiency extended surface pocket filter is the air filter specified by the manufacturer for the Menerga units. When we assessed air resistance of the reusable outdoor air filters, we found that air velocity in the outdoor air intake plenum changed from 200 feet per minute to 1,000 feet per minute when the air filter was removed, indicating substantial air resistance through the filter, which could adversely affect outdoor airflow rates.

A number of different consensus standards and guidelines can be used for assessing the ventilation system at the indoor waterpark: (1) the ASHRAE and ANSI publication ANSI/ ASHRAE Standard 62.1-2016, Ventilation for Acceptable Indoor Air Quality [ASHRAE 2016]; (2) the 2006 World Health Organization (WHO) Guidelines for Safe Recreational Water Environments, Volume 2, Swimming Pools and Similar Environments [WHO 2006]; (3) the 2011 ASHRAE Handbook - Heating, Ventilating, and Air-Conditioning Applications [ASHRAE 2015]; and (4) the Model Aquatic Health Code [CDC 2016f]. These standards are periodically updated on the basis of latest scientific research.

We used the estimated total square footage and supply airflow rate of the waterpark to compare the waterpark's ventilation rate to the rates recommended in the Model Aquatic Health Code. The Model Aquatic Health Code, which was released in 2016, generally adopts the ASHRAE handbook guidelines and ASHRAE standard 62.1-2016 for ventilation 
requirements [CDC 2016f]. The Model Aquatic Health Code ventilation requirements were developed to assure the health and comfort of aquatic facility users. ASHRAE 62.1-2016 requires minimum outdoor air ventilation rates for acceptable indoor air quality of enclosed spaces. This ANSI/ASHRAE standard ventilation rate is based on the amount of air believed to be sufficient to dilute building and occupant generated contaminants to an acceptable limit. This standard recommends a minimum of $0.48 \mathrm{cfm} / \mathrm{ft}^{2}\left(2.4\right.$ liters $/$ second per $\left.\mathrm{meter}^{2}\right)$ of outdoor air to ventilate pool and deck areas of indoor pool facilities. Based on the estimated size of 40,700 square feet, this standard recommends approximately 19,600 cfm of outdoor air. When operating as designed (but not during this visit), the HRUs should meet this standard when in air recirculation mode.

The ASHRAE Handbook: HVAC Applications, Places of Assembly, Natatoriums recommends an outdoor air delivery rate of 6-8 air changes per hour and that pool and spa areas be maintained at a negative pressure of 0.05 to 0.15 inches of water relative to outdoors and adjacent areas to prevent chloramine odor migration [ASHRAE 2015]. We did not measure the air change rate, but at the time of the site visit, we determined that the waterpark was under negative pressure with respect to the main hotel and all party rooms along the perimeter of the waterpark. This situation may be different if the air handling units were all operational.

\section{Review of Waterpark Records}

We reviewed 36 incident reports in the waterpark from January 31, 2015, to January 17, 2016. One waterpark employee with asthma experienced chest pain and difficulty breathing and received supplemental oxygen during our January 2016 site visit. Eleven other incident reports mentioned patrons with difficulty breathing, for a total of 12 of $36(33 \%)$ incidents during this period. The waterpark's policy to call emergency medical services if supplemental oxygen is given by waterpark staff was followed in all 12 incidents. Nineteen (53\%) of the incidents involved injury with blood loss mentioned. Waterpark staff responding to these incidents are potentially exposed to blood or body fluids contaminated with blood. Glove use was not mentioned in the incident reports, but we observed that disposable gloves were available in the waterpark and waterpark staff wore gloves when cleaning up fecal accidents.

We learned that waterpark supervisors do not readily have emergency contact information for waterpark employees in case of an emergency.

We reviewed 146 fecal accident reports from January 1, 2015, to January 17, 2016. These reports also described instances where vomitus, blood, or urine was discovered and cleaned by waterpark staff. During this time period, there were 102 reports involving vomitus, 41 involving stool, 1 involving blood, 1 involving urine, and 1 involving vomitus and stool.

\section{Observations}

Some of the maintenance staff voluntarily used goggles and respirators when working with pool chemicals in the chemical room. The half-mask elastomeric respirators with acid gas, organic vapor, and P100 cartridges used by maintenance employees were not properly maintained and were improperly stored in a stack on a metal shelf in a cabinet. 
The employees did not remember when they were trained on the potential health hazards associated with the pool chemicals or the proper use and storage of the respirators. There was no written respiratory protection program.

One of the surge tanks on the ventilation floor overflowed frequently. Maintenance employees told us that they occasionally had to enter the water surge tanks where the pools and water features drain and compensate for water pressure changes. We did not observe this; however, the surge tanks would be considered a confined space according to NIOSH. Additionally, the surge tanks might be considered a permit-required confined space on the basis of the Occupational Safety and Health Administration (OSHA) confined space standard [29 CFR 1910.146], because the tanks had "limited entry and exit" through the 4-foot-wide trap door [OSHA 2007].

The chemical storage room did not have mechanical ventilation. The employees told us that they kept the outside fire door to the chemical room open when working with the pool chemicals. During our visit, the waterpark maintenance employees used rubber gloves when adding chemicals to the water supply and goggles.

We observed pipes from the ventilation units that were supposed to drain into the sewer lines leaking into the pump room below. The pipes had either separated from the adjoining pipes or the metal band clamps that held the pipes together were rusted through, missing, or broken. Employees were using shop vacuums to remove the water.

\section{Discussion}

We found that waterpark employees were 4.91 times more likely than non-waterpark employees to meet the case definition for illness consistent with disinfection byproduct exposure [Fantuzzi et al. 2010; Parrat et al. 2012]. Eye irritation, cough, and nose irritation were the most common work-related symptoms reported by employees. Similarly, at a previous NIOSH evaluation of an indoor waterpark, eye irritation, cough, and nose irritation were the work-related symptoms most commonly reported by employees working in the waterpark area [NIOSH 2008]. In addition, Dutch investigators found that 624 swimming pool employees had a higher prevalence of self-reported respiratory symptoms than the general Dutch population. Upper respiratory symptoms were associated with cumulative exposure to chloramines, a class of disinfection byproducts (Appendix B) [Jacobs et al. 2007].

Of note, all 10 waterpark employees who reported current asthma diagnosed by a healthcare provider reported that their asthma seemed worse at work. Two waterpark employees reported their asthma began after starting to work at the waterpark. Work-related asthma, which includes work-related exacerbation of existing asthma and new-onset asthma, has been identified in swimming pool workers. From 1991 to 2011, 44 cases of confirmed work-related asthma were identified in three states that conduct surveillance for work-related asthma. Maintenance workers and lifeguards were the most common occupations of swimming pool workers with work-related asthma [Rosenman et al. 2015]. We did not obtain medical records of employees or perform any lung function testing to confirm the diagnosis of asthma. 
We found that a higher proportion of waterpark employees had skin rash than non-waterpark employees. Similarly, investigators also found a higher prevalence of skin rash in the past 4 weeks among exposed workers compared with non-exposed workers in a prior NIOSH investigation at a waterpark [CDC 2009; NIOSH 2008]. Approximately one-third of swimming pool attendees with symptoms in one outbreak investigation reported skin rash [CDC 2007; Kaydos-Daniels et al. 2008]. In our evaluation, the most common areas for skin rashes among waterpark employees were the legs and arms. These areas are more frequently exposed to possible occupational skin irritants in the water such as chlorine compounds and disinfection byproducts. Chronic exposure to water has been associated with contact dermatitis among workers who perform "wet work" [Behroozy and Keegel 2014; Meding 2016]. Lifeguards rotate through stations where they might be immersed in water up to thigh level. Chlorine compounds are another potential occupational skin irritant. Swimming in chlorinated water has been associated with contact dermatitis in a few case reports [Neering 1977; Sasseville 1999]. A swimming instructor who developed itchy skin and rash when exposed to pool water had a contact allergy to aluminum chloride, which was used to treat the water [Stenveld 2012]. While these studies suggest that water and chlorine compounds can contribute to the rashes observed among waterpark employees, the precise mechanisms leading to contact dermatitis associated with chlorinated water are not clear. We did not observe the rashes or obtain medical records to determine the nature or cause of the rashes among employees.

We found low concentrations of chlorine and chloroform in air samples. The chloroform concentrations we measured (range: $0.000057 \mathrm{ppm}$ to $0.00054 \mathrm{ppm}$ ) were similar or lower than concentrations found in other studies of indoor pools. Fantuzzi and associates found that average airborne concentrations of chloroform, measured poolside at five facilities, were $0.00094 \pm 0.004$ ppm [Fantuzzi et al. 2001]. Tardif and associates reported average chloroform concentrations of $0.02445 \pm 0.015 \mathrm{ppm}$ for 41 indoor pools [Tardif et al. 2015]. Although the concentrations of chloroform in the air were well below OELs in our evaluation, its presence indicates the formation and potential for exposure to additional chlorine disinfection byproducts, such as chloramines, in the waterpark.

In some instances chlorine levels in the water were above or below the waterpark's internal guidelines. Improper water chemistry control, specifically abnormal levels of $\mathrm{pH}$ and combined chlorine, has been associated with respiratory and irritation symptoms in outbreak investigations at indoor swimming pools and waterparks [CDC 2007; Kaydos-Daniels et al. 2008; NIOSH 2008]. In most of these studies, the combined chlorine levels in the water were elevated on the days symptoms were reported.

We found that the HVAC systems were not well maintained, which likely contributed to symptoms among waterpark employees. In the six large Menerga HRUs, we observed that many of the VFDs that control the HRU fan units were nonoperational or nonrepairable. We observed that many of the supply and return fans were not operating (Table A7). In addition, the original air filters supplied with the unit had been replaced with cleanable pocket-type filters. We found that air velocity in the outdoor air intake plenum increased when the air filter was removed, suggesting that the replacement filters may have reduced the amount of outdoor air delivered to the waterpark. 
When we compared the ventilation system design in the waterpark to the Model Aquatic Health Code and ASHRAE standard 62.1-2016, we found that this facility could meet current standards and guidelines if the systems were operating properly. However, many fans were not operational, which meant that the systems were performing below design specifications. These guidelines and standards were developed to provide adequate ventilation for still water-type pools similar to what one might encounter at a hotel, gym, or other small recreational facility. However, there are great differences between those types of pools and a large indoor leisure facility such as an indoor waterpark. Large waterparks have much larger volumes of heated water, large-scale water slides, and spray features. Water features generate more water droplets, which can influence the aerosolization of water contaminants. Additionally, the bather load is much higher than at a typical swimming pool facility. All of these factors affect the generation of airborne contaminants and ventilation system design and operation. An air quality formula that increased the minimum outdoor airflow requirement above ASHRAE 62.1-2016 to accommodate these factors was proposed but not adopted into the Model Aquatic Health Code [CDC 2016a].

In practice, the design of the air distribution system might be more important than the air exchange rate. At this waterpark, most supply and return airflow registers were placed high above the pool deck. This design is not consistent with a preferable pattern of air circulation that supplies air from overhead and returns air closer to deck level around the pools. The preferable design would help push disinfection byproducts in the air from the pool surface, where they are generated, towards the exhaust. Despite the fact that some high air returns may be necessary to account for tall water features and occupied areas, adequate airflow rates at the deck and pool surface are necessary to efficiently move contaminants such as disinfection byproducts from the pool to the return ducts so the contaminants can be diluted and exhausted from the building. Air returns located near the pool surface where contaminants are generated help maximize capture and minimize the likelihood of short circuiting [ASHRAE 2015; WHO 2006]. More air returns that are closer to the pool deck around the large pools are needed throughout the waterpark. Ideally, airflow across the pool surface and deck area should be minimized to prevent drafts on swimmers and reduce evaporation, but some airflow is required [Baxter 2012; Xie and Cooper 2006]. According to the ASHRAE handbook, some supply air should be directed over the water surface to move contaminated air towards the exhaust, but air movement should not exceed 30 feet per minute [ASHRAE 2015]. However, the priority for this facility should be to repair and maintain the existing systems prior to considering re-designing them.

We found that the temperature, $\mathrm{RH}$, and carbon dioxide measurements in the waterpark did not meet current ASHRAE standards and guidelines. Air temperatures were below the ASHRAE recommended levels of $75^{\circ} \mathrm{F}-85^{\circ} \mathrm{F}$ for hotel pools and whirlpool spas with the exception of the Lazy River area in the center of the waterpark on day 1 [ASHRAE 2015]. The temperatures also declined during the 3 days of our evaluation as the outdoor temperatures declined, indicating that the ventilation systems were not able to provide sufficient heating. It is recommended that air temperatures be $2^{\circ} \mathrm{F}-4^{\circ} \mathrm{F}$ above the water temperature to reduce evaporation and avoid chilling effects for the waterpark users [ASHRAE 2015]. In general, the RH levels in the waterpark (up to 100\%) exceeded current 
ASHRAE guidelines for RH of $50 \%-60 \%$ for buildings containing swimming pools [ASHRAE 2015]. Levels above 60\% can lead to mold growth. RH levels in other parts of the resort were low, which is typical during the winter heating season. Low humidity levels have been associated with symptoms of dry and irritated mucous membranes of the eyes and respiratory tract [Wolkoff and Kjærgaard 2007]. This might explain some of the symptoms reported by the non-waterpark employees. Carbon dioxide levels were higher than recommended for indoor environments, which may indicate insufficient outdoor air supply [ASHRAE 2015].

Water features greatly increase water droplet generation, which can influence the aerosolization of water contaminants. A study of an outbreak of granulomatous pneumonitis among lifeguards in an indoor swimming pool concluded that the disease was associated with endotoxin-containing respirable bioaerosols generated by water spray features [Rose et al. 1998]. This study determined that the operation of a water slide increased the number of respirable particles by 2.3 -fold and full water feature use increased the number of respirable particles by 5.2-fold. The researchers also concluded that full use of water features at that pool facility resulted in a 3.5-fold to 8-fold increase in mean air endotoxin concentrations. Improvements in the ventilation system at that facility did not prevent the recurrence of illness, but further study suggested that preventing the generation of water contaminants was necessary to prevent disease. This study reported mean endotoxin air levels of $76 \mathrm{EU} / \mathrm{m}^{3}$ and $28 \mathrm{EU} / \mathrm{m}^{3}$ for two separate sampling periods. We measured endotoxin levels (range: $3.6-68 \mathrm{EU} / \mathrm{m}^{3}$ ) that were similar to those found by Rose et al. and during a previous NIOSH waterpark investigation (range: $18-84$ EU/m³) [NIOSH 2008].

Two waterpark maintenance staff members reported work-related symptoms. We found that there was no written respiratory protection policy for waterpark maintenance staff who were voluntarily using respirators. We also found the chemical storage room had no ventilation. Also, a hazard communication program was lacking to educate maintenance staff about the chemicals being used.

We learned that waterpark employees are potentially exposed to blood and other body fluids when they respond to incidents in the waterpark and clean up biological materials. Although glove use was not specifically mentioned in the incident reports, we observed waterpark staff wearing gloves when cleaning up fecal accidents. This was consistent with the recommendation by CDC to wear disposable gloves when dealing with body fluid spills on pool surfaces or in the water because they may be contaminated with other pathogens [CDC 2016c]. Employees with exposure to blood or other potentially infectious materials are covered by the OSHA bloodborne pathogens standard [29 CFR 1910.1030]. OSHA has issued a memorandum affirming that lifeguards are covered by the standard [OSHA 1993].

Our evaluation has some limitations. First, our main evaluation occurred during the winter, when the waterpark was open for fewer hours and fewer seasonal employees were working. However, we still found that waterpark employees were more likely to have symptoms than non-waterpark employees. Second, we did not measure exposure to disinfection byproducts through the skin. Dermal absorption of disinfection byproducts is a recognized route of exposure [Dyck et al. 2011; WHO 2006]. Third, disinfection byproducts represent 
a large group of compounds, but we only measured levels of chloroform as a representative disinfection byproduct. For example, we did not evaluate levels of chloramines in air, which are also associated with irritative symptoms such as the ones we observed (Appendix B), because there is no reliable analytical method.

\section{Conclusions}

We found that employees had work-related eye and respiratory symptoms consistent with known hazards in waterparks. We found low concentrations of chloroform in the air samples from the waterpark, indicating potential exposure to disinfection byproducts. Water levels of combined chlorine were above the recommended guideline. The ventilation systems in the waterpark were not operating properly and did not meet current standards and guidelines at the time of the site visit. Temperatures were below and RH levels exceeded recommended guidelines. These environmental conditions likely contributed to the high prevalence of symptoms among waterpark employees. Repairing or replacing inoperable ventilation system components and maintaining the waterpark's ventilation systems should decrease the levels of disinfection byproducts and the likelihood of employees reporting symptoms [CDC 2016f].

\section{Recommendations}

On the basis of our findings, we recommend the actions listed below. We encourage the waterpark to use a labor-management health and safety committee or working group to discuss our recommendations and develop an action plan. Those involved in the work can best set priorities and assess the feasibility of our recommendations for the specific situation at the waterpark.

Our recommendations are based on an approach known as the hierarchy of controls (Appendix B). This approach groups actions by their likely effectiveness in reducing or removing hazards. In most cases, the preferred approach is to eliminate hazardous materials or processes and install engineering controls to reduce exposure or shield employees. Until such controls are in place, or if they are not effective or feasible, administrative measures and personal protective equipment may be needed.

\section{Engineering Controls}

Engineering controls reduce employees' exposures by removing the hazard from the process or by placing a barrier between the hazard and the employee. Engineering controls protect employees effectively without placing primary responsibility of implementation on the employee.

1. Complete maintenance service on the Menerga HRUs and repair or replace VFDs. Verify that all units and controls are operating properly and according to design specification.

a. Test and balance the HVAC systems to ensure adequate performance.

b. Work with the Menerga service representative to identify an air filter that provides sufficient filtration efficiency and minimizes air resistance.

2. Work with a qualified ventilation engineer to add more return air intakes and airflow at the pool and deck level near where contaminants are generated. These returns should 
redistribute some of the high air return volume to areas near the pool and deck areas.

3. Use source control options for reducing generation of airborne respirable particles, including: (1) spray heads that produce larger droplets, which may help reduce evaporation and aerosolization of contaminants; and (2) reducing the number of active cycles for water features, such as the large bucket dumps and waves.

4. Ventilate the chemical storage area to the outside [CDC 2016f].

\section{Administrative Controls}

The term administrative controls refers to employer-dictated work practices and policies to reduce or prevent hazardous exposures. Their effectiveness depends on employer commitment and employee acceptance. Regular monitoring and reinforcement are necessary to ensure that policies and procedures are followed consistently.

1. Develop a preventative maintenance schedule for the HVAC systems to ensure proper operation of the Menerga HRUs.

2. Limit access to the chemical storage and pump areas to maintenance staff. Keep the fire door from the chemical storage area to the outside closed but provide adequate room ventilation.

3. Encourage employees to promptly report any symptoms and implement a system to track such reports. Follow up on reports of symptoms to identify possible causes and correct problems.

4. Form a health and safety committee composed of managers and employees that meets regularly to address workplace health and safety concerns on an ongoing basis. Share information from the meetings with all employees.

5. Ensure that supervisors have readily available emergency contact information for all employees.

6. Follow the requirements of the OSHA bloodborne pathogens standard [29 CFR 1910.1030]. Suggestions for a model program can be found at https:/www.osha.gov/Publications/osha3186.pdf.

a. Assure that employees assigned to positions where they will potentially be exposed to blood and other potentially infectious materials receive bloodborne pathogen exposure control training on hire, before exposure.

b. Annually review the exposure control plan.

7. Clearly identify permit-required confined spaces, and control access to these spaces. Develop a written permit-required confined space entry program that includes information about the location of confined spaces, potential hazards, entry procedures, personal protective equipment, air monitoring procedures, and training. Additional information can be found at http://www.cdc.gov/niosh/topics/confinedspace/ and at https://www.osha.gov/SLTC/confinedspaces/index.html.

8. Develop a hazard communication program according to the OSHA hazard communication standard [29 CFR 1910.1200]. An essential part of the program is 
the identification of all hazardous chemicals an employee may be exposed to in the facility and how the chemicals should be handled. Additional guidance can be found in the OSHA document "Hazard Communication: Small Entity Compliance Guide for Employers That Use Hazardous Chemicals" at https://www.osha.gov/Publications/OSHA3695.pdf.

9. Encourage patrons and aquatics department employees to shower before entering the waterpark, which will decrease the amount of material from swimmers' bodies that react with chlorine to form disinfection byproducts.

\section{Personal Protective Equipment}

Personal protective equipment is the least effective means for controlling hazardous exposures. Proper use of personal protective equipment requires a comprehensive program and a high level of employee involvement and commitment. The right personal protective equipment must be chosen for each hazard. Supporting programs such as training, changeout schedules, and medical assessment may be needed. Personal protective equipment should not be the sole method for controlling hazardous exposures. Rather, personal protective equipment should be used until effective engineering and administrative controls are in place.

1. Provide employees with disposable non-latex (e.g., nitrile or vinyl) gloves for use when responding to incidents, cleaning up biological contaminants, and other times when it is reasonable to anticipate contact with blood, other potentially infectious materials, mucous membranes, or contaminated items or surfaces.

2. Provide employees who voluntarily wear half-mask elastomeric respirators a copy of Appendix D of the OSHA respiratory protection standard [29 CFR 1910.134] titled "Information for Employees Using Respirators When Not Required under the Standard." A written respirator program that covers medical fitness and proper maintenance procedures must be implemented. The OSHA Small Entity Compliance Guide for Respiratory Protection provides guidance on voluntary respirator use and additional information on respiratory protection at https://www.osha.gov/ Publications/3384small-entity-for-respiratory-protection-standard-rev.pdf.

3. Ensure safety goggles are worn when working with pool chemicals. 


\section{Appendix A: Tables}

Table A1. Area air sampling results for endotoxins on January 16-18, 2016

\begin{tabular}{|c|c|c|c|}
\hline Location & $\begin{array}{l}\text { Sample time } \\
\text { (minutes) }\end{array}$ & $\begin{array}{l}\text { Total volume } \\
\text { (liters) }\end{array}$ & $\begin{array}{l}\text { Concentration } \\
\left(E U / m^{3}\right)^{*}\end{array}$ \\
\hline \multicolumn{4}{|l|}{ January 16, 2016} \\
\hline Corner of Kiddie Korral/management office & 675 & 1357 & 24 \\
\hline Under stairs by Lazy River & 667 & 1342 & 37 \\
\hline Lazy River & 456 & 910 & 32 \\
\hline Rain Fortress & 677 & 1362 & 31 \\
\hline Side of Lazy River & 627 & 1261 & 68 \\
\hline Spa & 616 & 1229 & 35 \\
\hline Back desk of arcade & 626 & 1255 & 1.8 \\
\hline Concession stand & 562 & 1113 & 1.3 \\
\hline Outside & 627 & 1257 & 1.8 \\
\hline \multicolumn{4}{|l|}{ January 17, 2016} \\
\hline Corner of Kiddie Korral/management office & 641 & 1270 & 4.9 \\
\hline Under stairs by Lazy River & 646 & 1300 & 8.0 \\
\hline Towel service/party room & 643 & 1289 & 7.7 \\
\hline Rain Fortress & 654 & 1312 & 6.0 \\
\hline Side of Lazy River & 649 & 1305 & 3.6 \\
\hline Spa & 654 & 1315 & 4.3 \\
\hline Back desk of arcade & 641 & 1290 & 1.6 \\
\hline Concession stand & 586 & 1169 & 1.1 \\
\hline Outside & 654 & 1306 & 1.0 \\
\hline \multicolumn{4}{|l|}{ January 18, 2016} \\
\hline Corner of Kiddie Korral/management office & 409 & 797 & 7.1 \\
\hline Under stairs by Lazy River & 414 & 800 & 7.6 \\
\hline Towel service/party room & 413 & 802 & $N D^{*}$ \\
\hline Rain Fortress & 415 & 808 & 5.4 \\
\hline Side of Lazy River & 419 & 817 & 6.9 \\
\hline Spa & 433 & 828 & 15 \\
\hline Back desk of arcade & 419 & 808 & 4.5 \\
\hline Concession stand & 403 & 767 & $\mathrm{ND}^{*}$ \\
\hline ACGIH® TLV® & & & NA \\
\hline NIOSH REL & & & NA \\
\hline OSHA PEL & & & NA \\
\hline DECOS & & & 90 \\
\hline
\end{tabular}

$\mathrm{ND}=$ not detected

${ }^{*}$ The minimum detectable concentration of endotoxins ranged from $0.4 \mathrm{EU} / \mathrm{m}^{3}$ to $0.7 \mathrm{EU} / \mathrm{m}^{3}$. 
Table A2. Area air sampling results for chlorine on January 16-18, 2016

\begin{tabular}{|c|c|c|c|}
\hline Location & $\begin{array}{l}\text { Sample time } \\
\text { (minutes) }\end{array}$ & $\begin{array}{l}\text { Total volume } \\
\text { (liters) }\end{array}$ & $\begin{array}{l}\text { Concentration } \\
(\mathrm{ppm})^{*}\end{array}$ \\
\hline \multicolumn{4}{|l|}{ January 16, 2016} \\
\hline Corner of Kiddie Korral/management office & 675 & 678 & 0.067 \\
\hline Under stairs by Lazy River & 668 & 663 & $(0.090) \dagger$ \\
\hline Lazy River & 577 & 569 & 0.061 \\
\hline Rain Fortress & 677 & 687 & 0.061 \\
\hline Side of Lazy River & 627 & 623 & 0.053 \\
\hline Spa & 616 & 606 & 0.050 \\
\hline Back desk of arcade & 626 & 607 & ND \\
\hline Concession stand & 562 & 562 & ND \\
\hline Outside & 627 & 636 & ND \\
\hline \multicolumn{4}{|l|}{ January 17, 2016} \\
\hline Corner of Kiddie Korral/management office & 641 & 613 & 0.068 \\
\hline Under stairs by Lazy River & 646 & 606 & 0.092 \\
\hline Towel service/party room & 643 & 632 & 0.072 \\
\hline Rain Fortress & 322 & 317 & 0.10 \\
\hline Side of Lazy River & 649 & 625 & 0.056 \\
\hline Spa & 654 & 604 & 0.081 \\
\hline Back desk of arcade & 541 & 528 & ND \\
\hline Concession stand & 586 & 572 & 0.0031 \\
\hline Outside & 654 & 673 & ND \\
\hline \multicolumn{4}{|l|}{ January 18, 2016} \\
\hline Corner of Kiddie Korral/management office & 451 & 440 & 0.017 \\
\hline Under stairs by Lazy River & 414 & 419 & 0.077 \\
\hline Towel service/party room & 413 & 390 & $(0.065)$ \\
\hline Rain Fortress & 415 & 393 & $(0.065)$ \\
\hline Side of Lazy River & 419 & 402 & 0.078 \\
\hline Spa & 433 & 423 & $(0.069)$ \\
\hline Back desk of arcade & 419 & 397 & ND \\
\hline Concession stand & 403 & 394 & ND \\
\hline ACGIH TLV & & & 0.5 \\
\hline NIOSH REL & & & 0.5 (ceiling) \\
\hline OSHA PEL & & & 1 (ceiling) \\
\hline
\end{tabular}

${ }^{*}$ The minimum detectable concentration of chlorine ranged from $0.001 \mathrm{ppm}$ to $0.006 \mathrm{ppm}$.

†Values in parentheses are from samples that required dilution to bring the sample level within the curve of the analysis meaning there is more uncertainty associated with these results. 
Table A3. Area air sampling results for chloroform on January 16-18, 2016

\begin{tabular}{|c|c|c|c|}
\hline Location & $\begin{array}{l}\text { Sample time } \\
\text { (minutes) }\end{array}$ & $\begin{array}{l}\text { Total volume } \\
\text { (liters) }\end{array}$ & $\begin{array}{l}\text { Concentration } \\
(\mathrm{ppm})^{*}\end{array}$ \\
\hline \multicolumn{4}{|l|}{ January 16, 2016} \\
\hline Corner of Kiddie Korral/management office & 481 & 477 & 0.00019 \\
\hline Under stairs by Lazy River & 602 & 601 & 0.00037 \\
\hline Lazy River & 606 & 593 & 0.00026 \\
\hline Rain Fortress & 605 & 599 & 0.00047 \\
\hline Side of Lazy River & 628 & 622 & 0.00045 \\
\hline Spa & 484 & 478 & 0.00039 \\
\hline Back desk of arcade & 610 & 607 & $(0.000090) \dagger$ \\
\hline Concession stand & 562 & 552 & $0.00022 \ddagger$ \\
\hline Outside & 632 & 632 & $(0.000074)$ \\
\hline \multicolumn{4}{|l|}{ January 17, 2016} \\
\hline Corner of Kiddie Korral/management office & 641 & 635 & 0.00031 \\
\hline Under stairs by Lazy River & 635 & 319 & 0.00032 \\
\hline Towel service/party room & 642 & 628 & $0.00042 \ddagger$ \\
\hline Rain Fortress & 645 & 622 & 0.00020 \\
\hline Side of Lazy River & 654 & 645 & 0.00034 \\
\hline Spa & 654 & 637 & 0.00035 \\
\hline Back desk of arcade & 641 & 641 & $(0.00010)$ \\
\hline Concession stand & 589 & 580 & $(0.00010)$ \\
\hline Outside & 652 & 651 & $(0.000069)$ \\
\hline \multicolumn{4}{|l|}{ January 18, 2016} \\
\hline Corner of Kiddie Korral/management office & 353 & 343 & 0.00036 \\
\hline Under stairs by Lazy River & 355 & 345 & 0.00034 \\
\hline Towel service/party room & 354 & 346 & 0.00036 \\
\hline Rain Fortress & 354 & 342 & 0.00043 \\
\hline Side of Lazy River & 353 & 347 & 0.00054 \\
\hline Spa & 350 & 335 & 0.00037 \\
\hline Back desk of arcade & 333 & 324 & $(0.000057)$ \\
\hline Concession stand & 329 & 312 & ND \\
\hline ACGIH TLV & & & 10 \\
\hline NIOSH REL & & & $\begin{array}{c}2 \text { (Carcinogen - } \\
60 \text {-minute) }\end{array}$ \\
\hline OSHA PEL & & & 50 (ceiling) \\
\hline
\end{tabular}

*The minimum detectable concentration of chlorine ranged from $0.0005 \mathrm{ppm}$ to $0.0006 \mathrm{ppm}$.

†Values in parentheses are between the minimum detectable concentration and the minimum quantifiable concentration, meaning there is more uncertainty associated with these results.

$\ddagger$ One of the 2-hour samples showed breakthrough, meaning that the sample concentration is an estimate. 
Table A4. Water sampling results for free chlorine and combined chlorine on January 16-18, 2016

\begin{tabular}{|c|c|c|c|c|}
\hline & Time & $\begin{array}{l}\text { Free chlorine } \\
\quad(p p m)\end{array}$ & $\begin{array}{l}\text { Combined chlorine } \\
(\mathrm{ppm})\end{array}$ & Comments \\
\hline \multicolumn{5}{|l|}{ January 16, 2016} \\
\hline Slide & $1: 30 \mathrm{pm}$ & 4.0 & 0.4 & \\
\hline Spa & $1: 30 \mathrm{pm}$ & 1.5 & 0.4 & \\
\hline Lazy River & $1: 30$ pm & 1.0 & 0.4 & \\
\hline Kiddie Korral & $1: 30 \mathrm{pm}$ & 2.0 & 0.4 & \\
\hline \multicolumn{5}{|l|}{ January 17, 2016} \\
\hline Slide & $2: 15 \mathrm{pm}$ & 3.4 & 0.4 & \\
\hline Spa & $2: 15$ pm & 4.6 & 0.4 & \\
\hline Rain Fortress & $2: 15$ pm & 4.2 & 0.6 & \\
\hline Lazy River & $2: 15 \mathrm{pm}$ & 2.8 & 0.2 & \\
\hline Activity pool & $2: 15 \mathrm{pm}$ & 2.8 & 0.2 & \\
\hline Kiddie Korral & $2: 15 \mathrm{pm}$ & 3.2 & 0.2 & Cloudy appearance \\
\hline Slide & $6: 30 \mathrm{pm}$ & 2.8 & 0.2 & \\
\hline Spa & $6: 30 \mathrm{pm}$ & 5.4 & 0.6 & Cloudy appearance \\
\hline Rain Fortress & $6: 30$ pm & 3.8 & 0.4 & \\
\hline Lazy River & $6: 30 \mathrm{pm}$ & 3.8 & 0.2 & \\
\hline Activity pool & $6: 30 \mathrm{pm}$ & 3.2 & 0.4 & \\
\hline \multicolumn{5}{|l|}{ January 18, 2016} \\
\hline Slide & $11: 10 \mathrm{am}$ & 2.8 & 0.2 & \\
\hline Spa & $11: 10 \mathrm{am}$ & 1.8 & 0.4 & \\
\hline Rain Fortress & $11: 10 \mathrm{am}$ & 2.4 & 0.2 & \\
\hline Lazy River & $11: 10 \mathrm{am}$ & 3.0 & 0.2 & \\
\hline Activity pool & $11: 10 \mathrm{am}$ & 3.2 & 0.2 & \\
\hline Kiddie Korral & $11: 10 \mathrm{am}$ & 2.4 & 0.2 & \\
\hline Slide & $2: 00 \mathrm{pm}$ & 2.6 & 0.2 & \\
\hline Spa & $2: 00 \mathrm{pm}$ & 1.0 & 0.8 & High bather load \\
\hline Rain Fortress & $2: 00 \mathrm{pm}$ & 2.4 & 0.4 & \\
\hline Lazy River & $2: 00 \mathrm{pm}$ & 3.4 & 0.2 & \\
\hline Activity pool & $2: 00$ pm & 2.6 & 0.2 & \\
\hline Kiddie Korral & $2: 00 \mathrm{pm}$ & 3.2 & 0.2 & \\
\hline
\end{tabular}


Table A5. Indoor environmental quality measurements for temperature, relative humidity, and carbon dioxide using Q-Trak instruments on January 16-18, 2016

\begin{tabular}{|c|c|c|c|c|}
\hline Location & $\begin{array}{c}\text { Time } \\
\text { (minutes) }\end{array}$ & $\begin{array}{c}\text { Average } \\
\text { temperature } \\
{ }^{\circ} \mathrm{F} \text { (range) }\end{array}$ & $\begin{array}{c}\text { Average RH } \\
\% \text { (range) }\end{array}$ & $\begin{array}{c}\text { Average } \\
\text { carbon dioxide } \\
\text { ppm (range) }\end{array}$ \\
\hline \multicolumn{5}{|l|}{ January 16, 2016} \\
\hline Side of Lazy River & 571 & $\begin{array}{c}74.4 \\
(66.4-77.2)\end{array}$ & $\begin{array}{c}89.0 \\
(36.4-100)\end{array}$ & $\begin{array}{c}906 \\
(623-1216)\end{array}$ \\
\hline Spa & 600 & $\begin{array}{c}75.5 \\
(66.1-78.6)\end{array}$ & $\begin{array}{c}85.6 \\
(36.1-100)\end{array}$ & $\begin{array}{c}849 \\
(597-1020)\end{array}$ \\
\hline Back desk of arcade & 117 & $\begin{array}{c}70.2 \\
(68.2-72.8)\end{array}$ & $\begin{array}{c}19.3 \\
(18.4-21.5)\end{array}$ & $\begin{array}{c}586 \\
(509-728)\end{array}$ \\
\hline Gift shop & 610 & $\begin{array}{c}69.1 \\
(66.3-74.4)\end{array}$ & $\begin{array}{c}27.4 \\
(24.0-95.7)\end{array}$ & $\begin{array}{c}651 \\
(461-1158)\end{array}$ \\
\hline \multicolumn{5}{|l|}{ January 17, 2016} \\
\hline Spa & 610 & $\begin{array}{c}69.1 \\
(66.3-74.4)\end{array}$ & $\begin{array}{c}27.4 \\
(24-95.7)\end{array}$ & $\begin{array}{c}651 \\
(461-1158)\end{array}$ \\
\hline Back desk of arcade & 601 & $\begin{array}{c}69.5 \\
(66.2-72.5)\end{array}$ & $\begin{array}{c}16.2 \\
(11.4-22.8)\end{array}$ & $\begin{array}{c}565 \\
(467-769)\end{array}$ \\
\hline Gift shop & 712 & $\begin{array}{c}68.4 \\
(66.1-72.8)\end{array}$ & $\begin{array}{c}21.2 \\
(15.6-28.0)\end{array}$ & $\begin{array}{c}654 \\
(509-1378)\end{array}$ \\
\hline \multicolumn{5}{|l|}{ January 18, 2016} \\
\hline Spa & 402 & $\begin{array}{c}71.0 \\
(59.6-72.3)\end{array}$ & $\begin{array}{c}79.6 \\
(74.7-100)\end{array}$ & $\begin{array}{c}677 \\
(363-1455)\end{array}$ \\
\hline Back desk of arcade & 411 & $\begin{array}{c}68.8 \\
(65.7-71.1)\end{array}$ & $\begin{array}{c}6.70 \\
(5.1-13.2)\end{array}$ & $\begin{array}{c}543 \\
(492-644)\end{array}$ \\
\hline Gift shop & 431 & $\begin{array}{c}64.7 \\
(62.9-65.6)\end{array}$ & $\begin{array}{c}11.9 \\
(10.1-20.3)\end{array}$ & $\begin{array}{c}601 \\
(545-862)\end{array}$ \\
\hline
\end{tabular}


Table A6. Indoor environmental quality measurements for temperature and relative humidity using HOBO instruments on January 17-18, 2016

\begin{tabular}{|c|c|c|c|}
\hline Location* & $\begin{array}{c}\text { Time } \\
\text { (minutes) }\end{array}$ & $\begin{array}{c}\text { Average } \\
\text { temperature } \\
{ }^{\circ} \mathrm{F} \text { (range) }\end{array}$ & $\begin{array}{l}\text { Average } \mathrm{RH} \\
\% \text { (range) }\end{array}$ \\
\hline \multicolumn{4}{|l|}{ January 17, 2016} \\
\hline Corner of Kiddie Korral/management office & 671 & $\begin{array}{c}69.2 \\
(60.78-71.1)\end{array}$ & $\begin{array}{c}80.9 \\
(30.3-89.1)\end{array}$ \\
\hline Under stairs by Lazy River & 629 & $\begin{array}{c}73.6 \\
(70.4-74.5)\end{array}$ & $\begin{array}{c}69.4 \\
(51.8-77.8)\end{array}$ \\
\hline Rain Fortress & 631 & $\begin{array}{c}73.7 \\
(69.7-74.5)\end{array}$ & $\begin{array}{c}82.5 \\
(30.4-85.8)\end{array}$ \\
\hline Back desk of arcade & 645 & $\begin{array}{c}70.0 \\
(62.9-71.8)\end{array}$ & $\begin{array}{c}14.9 \\
(10.8-25.1)\end{array}$ \\
\hline Concession stand & 635 & $\begin{array}{c}69.3 \\
(60.1-71.8)\end{array}$ & $\begin{array}{c}13.7 \\
(7.2-51.0)\end{array}$ \\
\hline \multicolumn{4}{|l|}{ January 18, 2016} \\
\hline Corner of Kiddie Korral/management office & 488 & $\begin{array}{c}68.5 \\
(53.2-74.5)\end{array}$ & $\begin{array}{c}75.2 \\
(51.9-83.8)\end{array}$ \\
\hline Under stairs by Lazy River & 517 & $\begin{array}{c}68.2 \\
(51.8-71.08)\end{array}$ & $\begin{array}{c}66.7 \\
(28.7-80.2)\end{array}$ \\
\hline Towel service/party room & 512 & $\begin{array}{c}69.4 \\
(58.0-71.8)\end{array}$ & $\begin{array}{c}68.9 \\
(27.2-79.6)\end{array}$ \\
\hline Side of Lazy River & 475 & $\begin{array}{c}67.9 \\
(58.7-69.7)\end{array}$ & $\begin{array}{c}73.1 \\
(29.5-80.9)\end{array}$ \\
\hline Spa & 475 & $\begin{array}{c}69.2 \\
(61.5-71.8)\end{array}$ & $\begin{array}{c}78.4 \\
(34.8-82.7)\end{array}$ \\
\hline Back desk of arcade & 417 & $\begin{array}{c}69.4 \\
(59.4-71.08)\end{array}$ & $\begin{array}{c}8.20 \\
(6.5-48.5)\end{array}$ \\
\hline Concession stand & 410 & $\begin{array}{c}63.5 \\
(60.1-64.9)\end{array}$ & $\begin{array}{c}9.40 \\
(7.8-15.7)\end{array}$ \\
\hline
\end{tabular}

${ }^{*}$ Outside sample not reported due to equipment malfunction from temperatures below freezing all day 
Table A7. Design flowrates and observed operating conditions for the facility air conditioning units

\begin{tabular}{|c|c|c|c|c|}
\hline $\begin{array}{l}\text { Heat } \\
\text { recovery } \\
\text { unit number } \\
\text { (HRU) }\end{array}$ & $\begin{array}{l}\text { Supply } \\
\text { airflow } \\
\text { (ft } 3 / \mathrm{min})\end{array}$ & $\begin{array}{l}\text { Maximum } \\
\text { return } \\
\text { airflow } \\
\left(\mathrm{ft}^{3} / \mathrm{min}\right)\end{array}$ & $\begin{array}{l}\text { Menerga } \\
\text { unit type } \\
\text { (number) }\end{array}$ & Observations \\
\hline 1 & 18,834 & 18,834 & $\begin{array}{c}343201 \\
(110266)\end{array}$ & Supply fan not running, return fan running \\
\hline 2 & 18,834 & 18,834 & $\begin{array}{c}343201 \\
(110267)\end{array}$ & Supply and return fan running \\
\hline 3 & 14,714 & 14,714 & $\begin{array}{c}342501 \\
(110268)\end{array}$ & $\begin{array}{l}\text { Both supply and return fan running } \\
\text { although no flow was detected in supply } \\
\text { possibly due to a closed damper }\end{array}$ \\
\hline 4 & 14,714 & 14,714 & $\begin{array}{l}342501 \\
(110269)\end{array}$ & $\begin{array}{l}\text { Supply fan running, return fan appeared } \\
\text { to be not running }\end{array}$ \\
\hline 5 & 18,834 & 18,834 & $\begin{array}{c}343201 \\
(110270)\end{array}$ & Supply fan not running, return fan running \\
\hline 6 & 18,834 & 18,834 & $\begin{array}{c}343201 \\
(110271)\end{array}$ & Neither supply or return fan running \\
\hline $\begin{array}{l}\text { Total flow } \\
\left(\mathrm{ft}^{3} / \mathrm{min}\right)\end{array}$ & 104,767 & 104,767 & & \\
\hline
\end{tabular}




\section{Appendix B: Occupational Exposure Limits and Health Effects}

NIOSH investigators refer to mandatory (legally enforceable) and recommended OELs for chemical, physical, and biological agents when evaluating workplace hazards. OELs have been developed by federal agencies and safety and health organizations to prevent adverse health effects from workplace exposures. Generally, OELs suggest levels of exposure that most employees may be exposed to for up to 10 hours per day, 40 hours per week, for a working lifetime, without experiencing adverse health effects. However, not all employees will be protected if their exposures are maintained below these levels. Some may have adverse health effects because of individual susceptibility, a pre-existing medical condition, or a hypersensitivity (allergy). In addition, some hazardous substances act in combination with other exposures, with the general environment, or with medications or personal habits of the employee to produce adverse health effects. Most OELs address airborne exposures, but some substances can be absorbed directly through the skin and mucous membranes.

Most OELs are expressed as a time-weighted average (TWA) exposure. A TWA refers to the average exposure during a normal 8- to 10-hour workday. Some chemical substances and physical agents have recommended short-term exposure limits (STELs) or ceiling values. Unless otherwise noted, the STEL is a 15-minute TWA exposure. It should not be exceeded at any time during a workday. The ceiling limit should not be exceeded at any time.

In the United States, OELs have been established by federal agencies, professional organizations, state and local governments, and other entities. Some OELs are legally enforceable limits; others are recommendations.

- The U.S. Department of Labor OSHA permissible exposure limits (PELs) (29 CFR 1910 [general industry]; 29 CFR 1926 [construction industry]; and 29 CFR 1917 [maritime industry]) are legal limits. These limits are enforceable in workplaces covered under the Occupational Safety and Health Act of 1970.

- NIOSH recommended exposure limits (RELs) are recommendations based on a critical review of the scientific and technical information and the adequacy of methods to identify and control the hazard. NIOSH RELs are published in the NIOSH Pocket Guide to Chemical Hazards [NIOSH 2010a]. NIOSH also recommends risk management practices (e.g., engineering controls, safe work practices, employee education/training, personal protective equipment, and exposure and medical monitoring) to minimize the risk of exposure and adverse health effects.

- Other OELs commonly used and cited in the United States include the threshold limit values (TLVs), which are recommended by the American Conference of Governmental Industrial Hygienists, a professional organization, and the workplace environmental exposure limits (WEELs), which are recommended by the American Industrial Hygiene Association, another professional organization. The TLVs and WEELs are developed by committee members of these associations from a review of the published, peerreviewed literature. These OELs are not consensus standards. TLVs are considered 
voluntary exposure guidelines for use by industrial hygienists and others trained in this discipline "to assist in the control of health hazards" [ACGIH 2016]. WEELs have been established for some chemicals "when no other legal or authoritative limits exist" [AIHA 2016].

Outside the United States, OELs have been established by various agencies and organizations and include legal and recommended limits. The Institut für Arbeitsschutz der Deutschen Gesetzlichen Unfallversicherung (Institute for Occupational Safety and Health of the German Social Accident Insurance) maintains a database of international OELs from European Union member states, Canada (Québec), Japan, Switzerland, and the United States. The database, available at http://www.dguv.de/ifa/GESTIS/GESTIS-Internationale-Grenzwerte-fürchemische-Substanzen-limit-values-for-chemical-agents/index-2.jsp, contains international limits for more than 2,000 hazardous substances and is updated periodically.

OSHA requires an employer to furnish employees a place of employment free from recognized hazards that cause or are likely to cause death or serious physical harm [Occupational Safety and Health Act of 1970 (Public Law 91-596, sec. 5(a)(1))]. This is true in the absence of a specific OEL. It also is important to keep in mind that OELs may not reflect current health-based information.

When multiple OELs exist for a substance or agent, NIOSH investigators generally encourage employers to use the lowest OEL when making risk assessment and risk management decisions. NIOSH investigators also encourage use of the hierarchy of controls approach to eliminate or minimize workplace hazards. This includes, in order of preference, the use of (1) substitution or elimination of the hazardous agent, (2) engineering controls (e.g., local exhaust ventilation, process enclosure, dilution ventilation), (3) administrative controls (e.g., limiting time of exposure, employee training, work practice changes, medical surveillance), and (4) personal protective equipment (e.g., respiratory protection, gloves, eye protection, hearing protection). Control banding, a qualitative risk assessment and risk management tool, is a complementary approach to protecting employee health. Control banding focuses on how broad categories of risk should be managed. Information on control banding is available at http://www.cdc.gov/niosh/topics/ctrlbanding/. This approach can be applied in situations where OELs have not been established or can be used to supplement existing OELs.

\section{Disinfection Byproducts}

Disinfection byproducts are formed when the disinfectant chlorine reacts with organic and nitrogen-containing compounds in the water from swimmers' bodies. At recreational water venues, people are exposed to disinfection byproducts through skin contact with water containing disinfection byproducts, inhaling disinfection byproducts in the air, and swallowing water containing disinfection byproducts [Dyck et al. 2011; WHO 2006]. The concentration of disinfection byproducts in indoor aquatic venues depends on a number of factors, including water chemistry parameters (for example, chlorine concentration, $\mathrm{pH}$, and temperature), bather load, amount of splashing and spraying, and air recirculation [Baxter 2012; Chu and Nieuwenhuijsen 2002; Héry et al. 1995; Parrat et al. 2012]. Higher bather 
loads are associated with higher levels of trichloramine, a disinfection byproduct [Jacobs et al. 2007]. This is most likely due to the higher concentration of nitrogen-containing compounds in the water as the number of bathers increase. The two most-well studied types of disinfection byproducts are trihalomethanes (e.g., chloroform) and chloramines.

\section{Chloroform}

Trihalomethanes include four distinct but related compounds: chloroform $\left(\mathrm{CHCl}_{3}\right)$, bromodichloromethane $\left(\mathrm{CHCl}_{2} \mathrm{Br}\right)$, dibromochloromethane $\left(\mathrm{CHClBr}_{2}\right)$, and bromoform $\left(\mathrm{CHBr}_{3}\right)$. For chloroform, the current OSHA PEL is $50 \mathrm{ppm}$ as a ceiling [29 CFR 1910.1000]. NIOSH has established a STEL of 2 ppm over 60 minutes for chloroform. OSHA and NIOSH have designated chloroform to be a potential occupational carcinogen [NIOSH 2010]. The ACGIH TLV for chloroform is 10 ppm as a TWA for up to an 8-hour workday and 40-hour workweek.

Trihalomethanes, and in particular chloroform, are disinfection byproducts present in chlorinated swimming pools and other aquatic environments [WHO 2006]. Employees who work at swimming pools are more likely to report eye and respiratory symptoms as their exposure levels to trihalomethanes increase [Fantuzzi et al. 2010].

\section{Chloramines}

Chloramines are another type of disinfection byproduct found in recreational water venues. There are three types of chloramines: monochloramine $\left(\mathrm{NH}_{2} \mathrm{Cl}\right)$, dichloramine $\left(\mathrm{NHCl}_{2}\right)$, and trichloramine $\left(\mathrm{NCl}_{3}\right)$. Although chloramines are formed in the water when chlorine reacts with ammonia, they are volatile compounds that are found in the air in recreational water venues. Chloramines, especially trichloramine, are the main chemicals responsible for the "chlorine smell" in pools. Studies have found that chloramines are associated with eye, upper respiratory tract, and skin irritation [Jacobs et al. 2007; Massin et al. 1998]. One study found three employees who developed asthma after being exposed to trichloramine in a swimming pool environment [Thickett et al. 2002].

\section{Chlorine}

Chlorine is a greenish-yellow gas and has a pungent smell, with an odor threshold of approximately $0.3-0.5 \mathrm{ppm}$. Chlorine is moderately water soluble, so it can enter the upper and lower respiratory tract and often affects mucus membranes, eyes, and the lower respiratory tract. It forms hydrochloric and hypochlorous acid upon contact with water in the eyes, mucus membranes, and lower respiratory tract [Das and Blanc 1993]. The OSHA PEL for chlorine is $1 \mathrm{ppm}$ as a ceiling limit. A worker's exposure to chlorine shall at no time exceed this ceiling level [29 CFR 1910.1000]. NIOSH has established a REL for chlorine of $0.5 \mathrm{ppm}$ as a TWA for up to a 10-hour workday and a 40-hour workweek and a STEL of $1 \mathrm{ppm}\left(3 \mathrm{mg} / \mathrm{m}^{3}\right)$ [NIOSH 2010a]. The ACGIH TLV is $0.5 \mathrm{ppm}$ as a TWA for a normal 8-hour workday and a 40-hour workweek and a STEL of 1 ppm for periods not to exceed 15 minutes. Exposures at the STEL concentration should not be repeated more than four times a day and should be separated by intervals of at least 60 minutes [ACGIH 2016]. 


\section{Endotoxins}

Endotoxins are a lipopolysaccharide complexes found in the outer cell wall of Gram-negative bacteria. Endotoxin is released when bacteria die [Hagmar et al. 1990; Olenchock 1997]. Gram-negative bacteria are ubiquitous in the environment. Endotoxins produce a wide range of biological responses including blood vessel changes, inflammation, and allergic reactions. Airborne endotoxin exposures between 45 and $400 \mathrm{EU} / \mathrm{m}^{3}$ have been associated with symptoms of cough, wheeze, shortness of breath, chest tightness, and mucous membrane irritation, and signs of acute airflow obstruction [Castellan et al. 1987; Milton et al. 1996; Smid et al. 1994]. Chronic health effects that have been associated with airborne endotoxin exposures include chronic bronchitis, bronchial hyperreactivity, chronic airways obstruction, hypersensitivity pneumonitis, and emphysema [Castellan 1995]. A permanent decrease in pulmonary function, along with respiratory symptoms, has been reported in epidemiologic studies [DECOS 2010]. Endotoxin exposure has also been associated with skin itch and rash [Manfreda et al. 1986], but these associations have not been well documented.

Although scientists agree that endotoxins can cause human health effects, no universally accepted OELs have been developed because of the variability in sampling and analytical methods and a lack of data showing a consistent dose-response relationship. The Limulus amebocyte lysate assay is the most commonly used method of analyzing endotoxin [Milton 1999].

In the Netherlands, the Dutch Expert Committee on Occupational Standards has recommended a health-based exposure limit of $90 \mathrm{EU} / \mathrm{m}^{3}$ for airborne endotoxin in the working environment, averaged over an 8-hour working day. This exposure level is regarded as a no-observed-effect level [DECOS 2010]. This proposed OEL is based on epidemiologic studies showing evidence of respiratory health effects at concentrations near this level [Castellan et al. 1987; DECOS 2010].

\section{Legionella}

Legionella is a bacterium that causes legionellosis, which includes both Legionnaire's disease and Pontiac fever. Each year, an estimated 8,000 to 18,000 people in the United States are hospitalized with Legionnaire's disease, a type of pneumonia [CDC 2016e]. At least 59 species [Euzeby 2016] and 70 serogroups [Fields et al. 2002] have been identified in the Legionella genus. Although many Legionella species can cause health problems, most human infections are caused by Legionella pneumophilia. Legionella is transmitted via inhalation of aerosolized water containing the bacteria; it is usually not transmitted from person to person. Legionella thrives in warm environments $\left(32^{\circ} \mathrm{C}-45^{\circ} \mathrm{C}\right)$.

The symptoms of Legionnaire's disease are similar to other forms of pneumonia, which include high fever, chills, and cough. Some individuals may also experience shortness of breath, muscle aches, and headaches [CDC 2016e]. Symptoms begin 2 to 10 days after exposure. Hospitalization is common, but Legionnaire's disease can usually be successfully treated with antibiotics. Pontiac fever is a self-limited flulike illness. Symptoms include fever, chills, and malaise, which usually begin 24 to 72 hours after exposure.

Four outbreaks associated with Legionella in recreational water venues in 2009-2010 have 
been reported [CDC 2014]. Outbreaks of Legionnaire's disease have been linked to a variety of warm water systems or devices that produce aerosols, sprays or mists, including whirlpool spas [Ahmed and Mustfa 2014; Benkel et al. 2000; Jernigan et al. 1996; Principe et al. 2016]. Exposure to hot tubs is a recognized risk factor for legionellosis. CDC has recommended best practices for hot tub maintenance and operation [CDC 2016g] and disinfection of hot tubs contaminated with Legionella [CDC 2016d].

\section{Mycobacteria}

Nontuberculous mycobacteria are rod-shaped bacteria found in a great variety of natural and human-influenced aquatic environments, including in and around swimming pools, hot tubs, spas, and municipal water sources. They can concentrate in biofilms [Steed and Falkinham 2006]. Aerosolization occurs readily when airborne droplets form as bubbles burst at the water surface.

Nontuberculous mycobacteria are not transmitted from person to person, with very rare exceptions. Most infections from nontuberculous mycobacteria are acquired from the environment. Recently, reports have linked exposure to various species of mycobacteria in pools and natural waters to the development of respiratory disease [Pond 2005]. For example, Mycobacterium avium complex has been linked to hypersensitivity pneumonitis and possibly pneumonia in spa users [Embil et al. 1997]. Patients had flulike symptoms including cough, dyspnea (difficulty breathing), fever, chills, and malaise. The illnesses followed the inhalation of heavily contaminated aerosols generated in a spa. Among spa workers, maintenance workers with more exposure to aerosolized spa water were more likely to report more symptoms compatible with hypersensitivity pneumonitis (cough, wheezing, shortness of breath, fever, chills, aches, malaise, and weight loss) than workers with less or no exposure to aerosolized spa water [Moraga-McHaley et al. 2013].

Because of the high lipid content of their cell wall, nontuberculous mycobacteria are very resistant to the disinfectants used in water treatment, including chlorine and ozone [Engelbrecht et al. 1977; Falkinham 2003]. There are no specific guidelines to prevent nontuberculous mycobacteria from growing in recreational water venues. Thorough cleaning of surfaces and materials around pools and spas where the organism may persist is also necessary [WHO 2006]. 


\section{References}

ACGIH [2016]. 2016 TLVs ${ }^{\circledR}$ and BEIs ${ }^{\circledR}:$ threshold limit values for chemical substances and physical agents and biological exposure indices. Cincinnati, OH: American Conference of Governmental Industrial Hygienists.

Ahmed M, Mustfa N [2014]. Hot tub legionella pneumonia outbreak. Eur Respir J 44(5):1379-1381, http://dx.doi.org/10.1183/09031936.00005114.

AIHA [2016]. AIHA 2016 emergency response planning guidelines (ERPG) \& workplace environmental exposure levels (WEEL) handbook. Fairfax, VA: American Industrial Hygiene Association.

ASHRAE [2015]. ASHRAE Handbook-HVAC applications. Atlanta, GA: American Society of Heating, Refrigerating, and Air-Conditioning Engineers, Inc.

ASHRAE [2016]. Standard 62.1-2016, ventilation for acceptable indoor air quality. Atlanta, GA: American Society of Heating, Refrigerating, and Air-Conditioning Engineers, Inc.

Baxter RC [2012]. Designing for IAQ in natatoriums. ASHRAE Journal. 54(4):24-33.

Behroozy A, Keegel TG [2014]. Wet-work exposure: a main risk factor for occupational hand dermatitis. Saf Health Work 5(4):175-180, http://dx.doi.org/10.1016/j.shaw.2014.08.001.

Benkel DH, McClure EM, Woolard D, Rullan JV, Miller GB, Jenkins SR, Hershey JH, Benson RF, Pruckler JM, Brown EW, Kolczak MS, Hackler RL, Rouse BS, Breiman RF [2000]. Outbreak of Legionnaires' disease associated with a display whirlpool spa. Int J Epidemiol 29(6):1092-1098, http://dx.doi.org/10.1093/ije/29.6.1092.

Cambrex [2005]. Limulus Amebocyte Lysate (LAL), Kinetic-QCL. Catalog Number: 50650U. Walkersville, MD.

Castellan RM [1995]. Respiratory health effects of inhaled endotoxins: byssinosis and beyond. In: McDuffie H, Dosman J, Semchuk K, Olenchock S, eds. Agricultural health and safety: workplace, environment, sustainability. Boca Raton, FL: CRC Press.

Castellan RM, Olenchock SA, Kinsley KB, Hankinson JL [1987]. Inhaled endotoxin and decreased spirometric values. An exposure-response relation for cotton dust. N Engl J Med 317(10):605-610, http://dx.doi.org/10.1056/NEJM198709033171005.

CDC [2005]. Procedures for the recovery of Legionella from the environment. Atlanta, GA: Centers for Disease Control and Prevention, http://www.cdc.gov/legionella/health-depts/invtools-cluster/lab-inv-tools/procedures-manual.pdf.

CDC [2007]. Ocular and respiratory illness associated with an indoor swimming poolNebraska, 2006. MMWR 56(36):929-932, http://www.cdc.gov/mmwr/preview/mmwrhtml/mm5636a1.htm. 
CDC [2009]. Respiratory and ocular symptoms among employees of a hotel indoor waterpark resort-Ohio, 2007. MMWR 58(4):81-85, https://www.cdc.gov/mmwr/preview/mmwrhtml/mm5804a3.htm.

CDC [2014]. Pool chemical-associated health events in public and residential settingsUnited States, 2003-2012, and Minnesota, 2013. MMWR 63(19):427-430, http://www.cdc.gov/mmwr/preview/mmwrhtml/mm6319a3.htm.

CDC [2016a]. 2016 Annex to the Model Aquatic Health Code: scientific rationale. Atlanta, GA: U.S. Department of Health and Human Services, Centers for Disease Control and Prevention, http://www.cdc.gov/mahc/pdf/2016-mahc-annex-final.pdf.

CDC [2016b]. Chloramines \& pool operation. Atlanta, GA: U.S. Department of Health and Human Services, Centers for Disease Control and Prevention, http://www.cdc.gov/healthywater/swimming/aquatics-professionals/chloramines.html.

CDC [2016c]. Cleaning up body fluid spills on pool surfaces. Atlanta, GA: U.S. Department of Health and Human Services, Centers for Disease Control and Prevention, National Center for Immunization and Respiratory Diseases, http://www.cdc.gov/healthywater/swimming/pdf/cleaning-body-fluid-spills-factsheet.pdf.

CDC [2016d]. Disinfection of hot tubs contaminated with Legionella. Atlanta, GA: U.S. Department of Health and Human Services, Centers for Disease Control and Prevention, National Center for Immunization and Respiratory Diseases, http://www.cdc.gov/legionella/downloads/hot-tub-disinfection.pdf.

CDC [2016e]. Legionella (Legionnaire's Disease and Pontiac Fever). Atlanta, GA: U.S. Department of Health and Human Services, Centers for Disease Control and Prevention, National Center for Immunization and Respiratory Diseases, htttp://www.cdc.gov/legionella/index.html.

CDC [2016f]. Model Aquatic Health Code: the code, 2nd ed. Atlanta, GA: U.S. Department of Health and Human Services, Centers for Disease Control and Prevention, http://www.cdc.gov/mahc/editions/current.html.

CDC [2016g]. Operating public hot tubs. Atlanta, GA: U.S. Department of Health and Human Services, Centers for Disease Control and Prevention, National Center for Immunization and Respiratory Diseases, http://www.cdc.gov/healthywater/pdf/swimming/resources/operating-public-hot-tubsfactsheet.pdf.

Chu H, Nieuwenhuijsen M [2002]. Distribution and determinants of trihalomethane concentrations in indoor swimming pools. Occup Environ Med 59(4):243-247, http://doi.dx.org.10.1136/oem.59.4.243.

CFR. Code of Federal Regulations. Washington, DC: U.S. Government Printing Office, Office of the Federal Register. 
Das R, Blanc R [1993]. Chlorine gas exposure and the lung: a review. Toxicol Ind Health 9(3):439-455, http://doi:10.1177/074823379300900304.

DECOS [2010]. Endotoxins: health-based recommended occupational exposure limit. The Hague, Netherlands: Health Council of The Netherlands, Dutch Expert Committee on Occupational Standards, https:/www.gezondheidsraad.nl/sites/default/files/201004OSH.pdf.

Dyck R, Sadiq R, Rodriguez MJ, Simard S, Tardif R [2011]. Trihalomethane exposures in indoor swimming pools: a level III fugacity model. Water Res 45(16):5084-5098, http://dx.doi.org.10.1016/j.watres.2011.07.005.

Embil J, Warren P, Yakrus M, Stark R, Corne S, Forrest D, Hershfield E [1997]. Pulmonary illness associated with exposure to Mycobacterium-avium complex in hot tub water. Hypersensitivity pneumonitis or infection? Chest 111(3):813-816, http://dx.doi.org/10.1378/chest.111.3.813.

Engelbrecht RS, Severnin BF, Massarik MT, Faroo S, Lee SH, Haas CN, Lalchandani A [1977]. New microbial indicators of disinfection efficiency. Washington, DC: United States Environmental Protection Agency, Technological Series No. EPA 600/2-77-052.

Euzeby JP [2016]. List of prokaryotic names with standing in nomenclature-genus Legionella, http://www.bacterio.cict.fr/legionella.html.

Falkinham JO [2003]. Mycobacterial aerosols and respiratory disease. Emerg Infect Dis 9(7):763-767, http://dx.doi.org/10.3201/eid0907.02-0415.

Fantuzzi G, Righi E, Predieri G, Ceppelli G, Gobba F, Aggazzotti G [2001]. Occupational exposure to trihalomethanes in indoor swimming pools. Sci Total Environ 264(3):257-265, http://dx.doi.org/10.1016/S0048-9697(00)00722-1.

Fantuzzi G, Righi E, Predieri G, Giacobazzi P, Mastroianni K, Aggazzotti G [2010]. Prevalence of ocular, respiratory and cutaneous symptoms in indoor swimming pool workers and exposure to disinfection by-products (disinfection byproducts). Int J Environ Res Public Health 7(4):1379-1391, http://dx.doi.org/10.3390/ijerph7041379.

Fields BS, Benson RF, Besser RE [2002]. Legionella and Legionnaires' disease: 25 years of investigation. Clin Microbiol Rev 15:506-526, http://dx.doi.org/10.1128/cmr.15.3.506-526.2002.

Hagmar L, Schütz A, Hallberg T, Sjöholm A [1990]. Health effects of exposure to endotoxins and organic dust in poultry slaughter-house workers. Int Arch Occup Environ Health 62(2):159-164, http://dx.doi.org/10.1007/BF00383592.

Héry M, Hecht G, Gerber JM, Gender JC, Hubert G, Rebuffaud J [1995]. Exposure to chloramines in the atmosphere of indoor swimming pools. Ann Occup Hyg 39(4):427-439, http://dx.doi.org/10.1093/annhyg/39.4.427.

Jacobs JH, Spaan S, van Rooy GBGJ, Meliefste C, Zaat VAC, Rooyackers JM, Heederik D [2007]. Exposure to trichloramine and respiratory symptoms in indoor swimming pool workers. Eur Respir J 29(4):690-698, http://dx.doi.org/10.1183/09031936.00024706. 
Jernigan DB, Hofmann J, Cetron MS, Nuorti JP, Fields BS, Benson RF, Breiman RF, Lipman HB, Carter RJ, Genese CA, Paul SM, Edelstein PH, Guerrero IC [1996]. Outbreak of Legionnaires' disease among cruise ship passengers exposed to a contaminated whirlpool spa. Lancet 347(9000):494-499, http://dx.doi.org/10.1016/S0140-6736(96)91137-X.

Kaydos-Daniels SC, Beach MJ, Shwe T, Magri J, Bixler D [2008]. Health effects associated with indoor swimming pools: a suspected toxic chloramine exposure. Public Health 122(2):195-200, http://dx.doi.org/10.1016/j.puhe.2007.06.011.

Manfreda J, Holford-Strevens V, Cheang M, Warren CPW [1986]. Acute symptoms following exposure to grain dust in farming. Environ Health Perspect 66:73-80, http://www.ncbi.nlm.nih.gov/pmc/articles/PMC1474397.

Massin N, Bohadana AB, Wild P, Héry M, Toamain JP, Hubert G [1998]. Respiratory symptoms and bronchial responsiveness in lifeguards exposed to nitrogen trichloride in indoor swimming pools. Occup Environ Med 55(4):258-263, http://www.ncbi.nlm.nih.gov/pmc/articles/PMC1757567.

Meding B, Anveden Berglind I, Alderling M, Lindahl G, Wrangsjo K [2016]. Water exposure - challenging differences between occupations. Contact Dermatitis 74(1):22-28, http://dx.doi.org/10.1111/cod.12479.

Milton DK [1999]. Endotoxin and other bacterial cell-wall components. In: Macher J, ed. Bioaerosols: assessment and control. Cincinnati, $\mathrm{OH}$ : American Conference of Governmental Industrial Hygienists.

Milton DK, Wypij D, Kriebel D, Walters MD, Hammond SK, Evans JS [1996]. Endotoxin exposure-response in a fiberglass manufacturing facility. Am J Ind Med 29(1):3-13, http://dx.doi.org/10.1002/(SICI)1097-0274(199601)29:1\%3c3::AID-AJIM2\%3e3.0.CO;2-V.

Moraga-McHaley SA, Landen M, Krapfl H, Sewell CM [2013]. Hypersensitivity pneumonitis with mycobacterium avium complex among spa workers. Int J Occup Environ Health 19(1):55-61, http://dx.doi.org/10.1179/2049396712y.0000000015.

Neering H [1977]. Contact urticaria from chlorinated swimming pool water. Contact Dermatitis 3(5):279, http://dx.doi.org/10.1111/j.1600-0536.1977.tb03679.x.

NIOSH [2008]. Investigation of employee symptoms at an indoor waterpark. By Chen L, Dang B, Mueller CA, Dunn KH, Almaguer D, Ernst JL, Otto CS. Cincinnati, OH: U.S. Department of Health and Human Services, Centers for Disease Control and Prevention, National Institute for Occupational Safety and Health, Health Hazard Evaluation Report 2007-0163-3062, https:/www.cdc.gov/niosh/hhe/reports/pdfs/2007-0163-3062.pdf.

NIOSH [2010a]. NIOSH pocket guide to chemical hazards. Cincinnati, OH: U.S. Department of Health and Human Services, Centers for Disease Control and Prevention, National Institute for Occupational Safety and Health, DHHS (NIOSH) Publication No. 2010-168c, http://www.cdc.gov/niosh/npg/. 
NIOSH [2010b]. Workplace solutions: reducing illnesses at indoor waterparks. Cincinnati, OH: U.S. Department of Health and Human Services, Centers for Disease Control and Prevention, National Institute for Occupational Safety and Health, DHHS (NIOSH) Publication No. 2010138, http://www.cdc.gov/niosh/docs/wp-solutions/2010-138/pdfs/2010-138.pdf.

NIOSH [2012]. Evaluation of eye and respiratory symptoms at a poultry processing plant Oklahoma. By Chen L, Eisenberg J, Durgam S, Mueller C. Cincinnati, OH: U.S. Department of Health and Human Services, Centers for Disease Control and Prevention, National Institute for Occupational Safety and Health, NIOSH Health Hazard Evaluation Report 2007-0284 and 2007-0317-3155, https:/www.cdc.gov/niosh/hhe/reports/pdfs/2007-0284-0317-3155.pdf.

NIOSH [2017]. NIOSH manual of analytical methods (NMAM). 5th ed. O'Connor PF, Ashley K, eds. Cincinnati, OH: U.S. Department of Health and Human Services, Centers for Disease Control and Prevention, National Institute for Occupational Safety and Health, DHHS (NIOSH) Publication No. 2014-151, http://www.cdc.gov/niosh/nmam.

Olenchock S [1997]. Airborne endotoxin. In: Hurst CJ, Knudsen GR, McInerney MJ, Stetzenbach LD, Walter MV, eds. Manual of environmental microbiology. Washington, DC: ASM Press.

OSHA [1993]. Coverage of lifeguards under 29 CFR 1910.1030. Washington, DC: U.S. Department of Labor, Occupational Safety and Health Administration, https://www.osha.gov/pls/oshaweb/owadisp.show_document?p $\underline{\text { table}=I N T E R P R E T A T I O N S \& p ~ i d=21197 . ~}$

OSHA [2007]. Safety and health topics: confined spaces. Washington, DC: U.S. Department of Labor, Occupational Safety and Health Administration, http://www.osha.gov/SLTC/confinedspaces/index.html.

Parrat J, Donze G, Iseli C, Perret D, Tomicic C, Schenk O [2012]. Assessment of occupational and public exposure to trichloramine in Swiss indoor swimming pools: a proposal for an occupational exposure limit. Ann Occup Hyg 56(3):264-277, http://doi.dx.org/10.1093/annhyg/mer125.

Pond KR [2005]. Water recreation and disease. Plausibility of associated infections: acute effects, sequelae and mortality. London: IWA Publishing, http://www.who.int/water_sanitation_health/bathing/recreadis/en/.

Principe L, Tomao P, Visca P [2016]. Legionellosis in the occupational setting. Environ Res, http://dx.doi.org/10.1016/j.envres.2016.09.018. Advance online publication.

Rosenman KD, Millerick-May M, Reilly MJ, Flattery J, Weinberg J, Harrison R, Lumia M, Stephens AC, Borjan M [2015]. Swimming facilities and work-related asthma. J Asthma 52(1):52-58, http://dx.doi.org/10.3109/02770903.2014.950428.

Rose CS, Martyny JW, Newman LS, Milton DK, King Jr TE, Beebe JL, McCammon JB, Hoffman RE, Kreiss K [1998]. "Lifeguard lung": endemic granulomatous pneumonitis in an indoor swimming pool. Am J Public Health 88(12):1795-1800, http://www.ncbi.nlm.nih.gov/pmc/articles/PMC1509038. 
Sasseville D, Geoffrion G, Lowry N [1999]. Allergic contact dermatitis from chlorinated swimming pool water. Contact Dermatitis 41(6):347-348, http://dx.doi.org/ 10.1111/j.1600-0536.1999.tb06190.x.

Smid T, Heederik D, Houba R, Quanjer PH [1994]. Dust- and endotoxin-related respiratory effects in the animal feed industry. Am Rev Respir Dis 146(6):1474-1479, http://onlinelibrary.wiley.com/doi/10.1002/ajim.4700250611/abstract;jsessionid=AA423C884 8AA737811337D108EF93D2F.f01t04.

Steed KA, Falkinham JO 3rd [2006]. Effect of growth in biofilms on chlorine susceptibility of Mycobacterium avium and Mycobacterium intracellulare. Appl Environ Microbiol 72(6):4007-4011, http://dx.doi.org/10.1128/aem.02573-05.

Stenveld H [2012]. Allergic to pool water. Safety and health at work 3(2):101-103, http://dx.doi.org/10.5491/shaw.2012.3.2.101.

Tardif R, Catto C, Haddad S, Rodriguez M [2015]. Assessment of worker exposure to disinfection byproducts at indoor swimming pools in Québec. The Institut de recherche Robert-Sauvé en santé et en sécurité du travail (IRSST), Studies and Research Projects, Chemical and Biological Hazard Prevention. Report R-894, http://www.irsst.qc.ca/media/documents/PubIRSST/R-894.pdf.

Thickett KM, McCoach JS, Gerber JM, Sadhra S, Burge PS [2002]. Occupational asthma caused by chloramines in indoor swimming-pool air. Eur Respir J 19(5):827-832, http://dx.doi.org/10.1183/09031936.02.00232802.

Villanueva CM, Cordier S, Font-Ribera L, Salas LA, Levallois P [2015]. Overview of disinfection by-products and associated health effects. Curr Environ Health Rep 2(1):107115, http://doi:10.1007/s40572-014-0032-x.

WHO [2006]. Guidelines for safe recreational water environments. Volume 2: swimming pools and similar environments. Geneva, Switzerland: World Health Organization, http://www.who.int/water_sanitation_health/bathing/srwe2begin.pdf.

Wolkoff P, Kjaergaard SK [2007]. The dichotomy of relative humidity on indoor air quality. Environ Int 33(6):850-857, http://dx.doi.org/10.1016/j.envint.2007.04.004.

Xie L, Cooper K [2006]. Natatoriums: the inside story. ASHRAE Journal 48(4):16-27, http://bookstore.ashrae.biz/journal/download.php?file=27786cooper_lan.pdf. 
Keywords: North American Industry Classification System 713110 (Amusement and Theme Parks), Ohio, waterpark, chloroform, chlorine, endotoxins, disinfection byproducts, cough, wheeze, shortness of breath, nose irritation, eye irritation, lifeguards, young workers 
The Health Hazard Evaluation Program investigates possible health hazards in the workplace under the authority of the Occupational Safety and Health Act of 1970 (29 U.S.C. § 669(a) (6)). The Health Hazard Evaluation Program also provides, upon request, technical assistance to federal, state, and local agencies to investigate occupational health hazards and to prevent occupational disease or injury. Regulations guiding the Program can be found in Title 42, Code of Federal Regulations, Part 85; Requests for Health Hazard Evaluations (42 CFR Part 85).

\section{Disclaimer}

The recommendations in this report are made on the basis of the findings at the workplace evaluated and may not be applicable to other workplaces.

Mention of any company or product in this report does not constitute endorsement by NIOSH.

Citations to Web sites external to NIOSH do not constitute NIOSH endorsement of the sponsoring organizations or their programs or products. NIOSH is not responsible for the content of these Web sites. All Web addresses referenced in this document were accessible as of the publication date.

\section{Acknowledgments}

Analytical Support: Bureau Veritas North America, Microbiology Specialists Inc.

Desktop Publisher: Shawna Watts

Editor: Ellen Galloway

Industrial Hygiene Field Assistance: Karl Feldmann, Jessica F. Li

Logistics: Donnie Booher, Kevin Moore

Medical Field Assistance: Marie de Perio, Candice Johnson, Carolyn McCarty, Chia-ping Su, Amanda Zabala

Statistical Support: Michelle Colvin, Denise Giglio, Charles Mueller

\section{Availability of Report}

Copies of this report have been sent to the employer and employees at the facility. The state and local health department and the Occupational Safety and Health Administration Regional Office have also received a copy. This report is not copyrighted and may be freely reproduced.

\section{Recommended citation for this report:}

NIOSH [2017]. Evaluation of eye and respiratory symptoms among employees at an indoor waterpark resort. By Chiu S, Burton N, Dunn KH. Cincinnati, OH: U.S. Department of Health and Human Services, Centers for Disease Control and Prevention, National Institute for Occupational Safety and Health, Health Hazard Evaluation Report 2015-0148-3272, http://www.cdc.gov/niosh/hhe/reports/pdfs/20150148-3272.pdf. 
Delivering on the Nation's promise:

Safety and health at work for all people through research and prevention

To receive NIOSH documents or more information about occupational safety and health topics, please contact NIOSH:

Telephone: 1-800-CDC-INFO (1-800-232-4636)

TTY: 1-888-232-6348

CDC INFO: www.cdc.gov/info

or visit the NIOSH Web site at www.cdc.gov/niosh

For a monthly update on news at $\mathrm{NIOSH}$, subscribe to $\mathrm{NIOSH}$ eNews by visiting www.cdc.gov/niosh/eNews. 